\title{
Effects of Economic and Political Events on Stock Returns: Event Study of the Agrokor Case in Croatia
}

\section{Tihana Škrinjarić}

Faculty of Economics and Business, University of Zagreb, Croatia tskrinjar@net.efzg.hr

\section{Zrinka Orlović}

Faculty of Economics and Business, University of Zagreb, Croatia zorlovic@net.efzg.hr

\author{
CroEconsur \\ Vol. 21 \\ No. 1 \\ June 2019 \\ pp. $47-86$
}

Received: July 11, 2018

Accepted: January 14, 2019

Research Article

doi:10.15179/ces.21.1.2

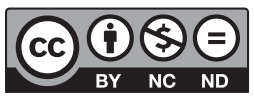

\section{Abstract}

Major events in Croatia regarding economy and politics in the last three years have been related to the Agrokor concern. Agrokor is one of the biggest companies/ concerns in Croatia and Southeastern Europe. Since some of Agrokor's stocks are listed on the Croatian stock market, the economic and political events regarding Agrokor have affected the stock market as well to an extent. In this study we observe the effects of several economic and political events on stock returns on the Zagreb Stock Exchange, by dividing the sample into two groups. The first group consists of Agrokor's stocks and the other group consists of stocks of other companies which are listed and frequently traded on the market. The methodology used in the study was event study, by using parametric and nonparametric tests. The results indicate that specific economic and political events 
have affected Agrokor's stock returns negatively. Other stock returns were not affected, or were affected positively, but not statistically significantly.

Keywords: Agrokor case, Zagreb Stock Exchange, economic and political events, abnormal return, non-parametric tests

JEL classification: G14, C58, C12

\section{Introduction}

Empirical testing of the efficient market hypothesis (Fama 1965, 1970) on stock markets has been extremely popular over the last couple of decades. Its semistrong form assumes that all public information is embedded into stock prices rapidly and new, unexpected information is evaluated almost instantaneously. Thus, price changes (returns) should reflect new information if the prices reflect all already available information. In that way, the size or the importance of an (economic, political, and other) event should be able to be visible and measurable in the time period in which the event occurs. Economic and political events are one of the factors which affect stock market prices the most. Harvey, Liu, and Zhu (2014) recorded many of them based upon an extensive review of previous literature (316 factors in total which include financial, economic, political, and other factors). There has been a growing interest in examining effects of specific events on stock markets. Cooper, Gulen, and Ovtchinnikov (2010) document many papers which found that stock prices react to announcements regarding the degree of political connectedness of a company. Political events in Croatia influence many segments of the economy, including the stock market, which was proven in several papers which have dealt with such questions (see Ivanov \& Lovrinović, 2008; Benazić, 2008; Hsing, 2011; or Barbić and Čondić-Jurkić, 2017). However, all of the mentioned papers deal with macroeconomic data, with monthly or quarterly frequencies. Moreover, these papers observe effects of expansive or restrictive fiscal or monetary policy on the stock market as a whole. To our knowledge, there are no studies that evaluate the effects of political events 
which can be observed in the short run, by using the event study methodology. This research includes several events which could be classified as political and observes stock price reactions to them.

Since major events in Croatia regarding economy and politics in the last three years have been related to the Agrokor concern, a special focus on this company will be provided in this study. Agrokor is one of the biggest companies/concerns in Croatia and Southeastern Europe, consisting mostly of food and soft drinks production and retail trade. It employs approximately 60,000 people (Agrokor, 2017) in Croatia and abroad. In the 2000s, this company spread out to the markets of Bosnia and Herzegovina and Serbia. In Croatia, the concern grew rapidly by acquiring other bigger companies in food production and retail trade (e.g., the largest Croatian retailer Konzum, the largest Croatian newsstand Tisak, the largest Croatian meat producer PIK Vrbovec, the largest agricultural-industrial company Belje). Some controversies occurred when the Slovenian big retail chain Mercator was acquired by Agrokor in 2014. Despite the outstanding growth and expansion of the Agrokor concern, many problems have been accumulating over the years. They mostly consist of Agrokor's borrowing rate growing faster than its revenue growth rate or operating profit growth. The company's problems became public at the beginning of 2017, when Moody's lowered Agrokor's rating from B2 to B3. This triggered a chain of events, which were mostly political in nature: a new extraordinary commissioner was appointed for the concern; new legislation was quickly established for this special case; due to animosities in the Croatian Parliament, Speaker of the Parliament Božo Petrov gave his resignation, etc. The case of Agrokor is still ongoing today; the concern did not go bankrupt yet, but the losses are outstanding, there are issues with the extradition of Ivica Todorić (former President of the Management Board) to Croatia due to his ongoing trial, and there are many open questions: how to reach a settlement with Agrokor's suppliers, how to pay back the debts, etc.

The Croatian stock market, Zagreb Stock Exchange (ZSE), is very shallow and illiquid, and it has had problems recovering since the last financial crisis in 2008. 
Some of Agrokor's companies are listed on the ZSE. Thus, the aforementioned events have affected the stock market as well. The Croatian Financial Services Supervisory Agency had been observing the price and trading movements on ZSE and demanded a suspension of trading in Agrokor stocks in April 2017 (Hanfa, 2017). The second quarter of 2017 experienced a slowdown of economic growth in Croatia due to uncertainties regarding the Agrokor case (Croatian National Bank, 2017). However, there is no formal empirical study, to our knowledge, which tries to quantify the extent of the mentioned events regarding Agrokor and their effects on stock market returns in Croatia. The debate on whether this was a political event or a collapse of one of the "too big to fail" companies is left for other types of studies. That is why we refer to specific events (both economic and political) which have happened surrounding Agrokor and give reasoning why they are considered economic and/or political. The political notation and classification and more details can be found in Rančić (2018) or Ivanković (2017). The "too big to fail" discussion, including considerations regarding the Agrokor case, can be found in Rubinić and Bodul (2018). The main approach here is that investors observe happenings in the economy and adjust their forecasts and investment decisions, as discussed in Schwert (1990) or Cochrane (2008).

This study has several goals. The first one is to fill the gap in researching the effects of economic and political events on stock prices and returns. The methodology used in this research is event study (MacKinlay, 1997), due to the main research hypotheses. The second goal is to evaluate how much the events regarding the Agrokor concern affect stock market returns due to its size in the Croatian economy. The main research hypotheses in the paper are the following ones. Negative economic and political events regarding Agrokor have significantly negatively affected the stock returns of Agrokor's companies. The term negative is not the perception of the authors per se; it is an assumption from the investor point of view (details are given in the empirical part of the research). The second research hypothesis states that those events did not have significant effects on the 
stock returns of other companies. The structure of the paper is as follows. The second section deals with related literature on the topic of event study of stock returns. The third section describes the methodology used in the paper and the fourth section deals with the empirical results. The final, fifth section concludes the paper.

\section{Literature Review}

By observing previous literature which has used event study methodology to estimate the effects of events on stock returns, it can be concluded that there are roughly two groups of studies. The first group of papers deal mostly with events regarding mergers and acquisitions and dividend policies. Thus, we can call them business events. This group is the largest one. The second group estimates the effects of political elections and events on stock returns. In that way, one can observe the effects of presidential elections on stock market returns or the effects of other political events, such as political risks due to ongoing wars or specific events such as the Agrokor case in Croatia. Here we give a brief overview of the more relatable and newer studies in order to gain more insights for the potential results in this study.

In the first group of papers, authors mostly deal with dividend announcements, mergers and acquisitions, and changes in business practices. Capstaff, Klaeboe, and Marshall (2004) tested the stock price reaction to dividend announcements on the Oslo Stock Exchange. The sample consisted of 64 firms in the period from 1993 to 1998, which included 201 dividend announcements. The estimation period in the model consisted of 250 days and the event window consisted of 21 days: 10 days before the announcement day and 10 days after the announcement. The authors proved that stock price reactions are associated with dividend decrease or increase announcements, whereas unchanged dividends do not affect the stock price. Also, the market reaction is greater if the change in dividend is larger. Miletić (2011) investigated the connection between dividend announcements 
and stock prices on the Croatian capital market from 2007 to 2009 . The sample consisted of three groups of companies: those that announced dividend increases (22 companies with 35 announcements), those announcing dividend decreases (10 companies and 11 announcements), and those with unchanged dividends (9 companies, 10 announcements). The period before the event window was 40 days and the event window was 7 days before the dividend announcements and 2 days after the announcements. One of the conclusions of the paper is that information about dividend changes is important for market investors. Furthermore, the connection between unexpected dividend increase and stock price increase is confirmed, as well as the connection between unexpected dividend decrease and stock price decrease. The connection between unchanged dividend and stock price is statistically insignificant. Mrzygłód and Nowak (2017) investigated how prices on the Polish stock market react to dividend announcements and dividend payouts made by companies listed on the Warsaw Stock Exchange. The sample in this study consisted of 56 companies that announced dividend payments and completed the payout during 2013, with an 11-day event window. The sample was divided into four different groups. The first group consisted of dividend announcements after a minimum one-year break, the next one of dividend increase announcements, the third group consisted of dividend decrease announcements, and the final group had constant dividend announcements. The results showed that the first two groups of dividend announcements have a positive impact on stock prices on the first day after the announcement, whereas dividend decrease announcements have a negative effect on stock prices which is visible two days after the announcements. Mlonzi, Kruger, and Nthoesane (2011) observed the existence of significant abnormal stock returns following public announcements of earnings. The authors included companies with stocks listed on the Johannesburg Stock Exchange that announced their annual earnings in 2009. The event window included ten pre-event days and five post-event days $\left(\left[-\tau_{\text {start }},+\tau_{\text {end }}\right]\right)$. The findings show that earnings announcements have a negative effect on stock prices during the recession period. 
Angelovska (2017) also uses traditional event study methodology to measure how stock prices react to firms' earnings announcements around the announcement day. The event window is defined as one day before the announcement day and two days after the announcement day. The author used daily returns of ten stocks listed on the Macedonian Stock Exchange during the 2008-2009 period. The results showed that the Macedonian investors did not react to companies' positive news during the recession period. Shaheen (2006) investigated how the stock market reacts to acquisition announcements using event study methodology. $\mathrm{He}$ observed how abnormal returns of target and acquiring firms react around the acquisition announcement day. The study included 467 merger announcements from January 1, 1997. He observed the announcement day and the day after, and concluded that abnormal returns are maximized on the announcement day. The event window consisted of five days before and five days after the announcement day. The empirical results showed that target firms experience significant positive abnormal returns around the announcement day, whereas target firms experience significant negative abnormal returns on the announcement day. Gopalaswamy, Acharya, and Malik (2008) observe the differences in stock price reactions of target and acquiring companies depending on merger announcements. They used data for Indian companies whose stocks are listed on the Bombay Stock Exchange (BSE) or National Stock Exchange (NSE). The sample for this study included 25 companies during the period from 2000 to 2007 . The authors used traditional event study methodology to see how the market reacts to merger announcements. For this analysis they used the following event windows (preand post-event days): $[-10,+5],[-15,+10],[-25,+15]$. The authors concluded that target and acquiring companies show an uptrend in the CAAR (cumulative average abnormal returns) a few days before the announcements. They also found that acquiring companies react stronger to merger announcements than target companies. Also, there is a sudden downfall in the CAAR for the target companies a day after the announcements. The authors concluded that the CAAR and AAR trend is in line with the expectation, which means that the Indian stock market is semi-strong efficient. Von Gersdorff and Bacon (2009) 
also tested how merger and acquisition announcements affect stock prices. The study consisted of 15 examples of mergers and acquisitions from April 2 to August 31, 2007. The sample included 20 acquiring firms which were all traded on the New York Stock Exchange (NYSE) or NASDAQ. The event period includes 30 days before the merger announcements and 30 days after. The findings show that there is a stock price reaction around the announcement day, but the merger announcement may not be the reason for abnormal returns. Chaudary and Mirza (2017) analyzed shareholder returns of UK banks acquiring domestic banks and cross-border banks within the European Union. The study showed the difference in the abnormal return in those two types of acquisitions. It covered the period from 2006 to 2013 and comprised a sample of 75 percent of total banks included in domestic and cross-border acquisitions. Using event study methodology, the authors set the event window to 15 days, which consisted of 7 days prior to and 7 days after the announcement date. The empirical evidence demonstrated that when UK banks are acquiring cross-border banks, shareholder returns are statistically insignificant and negative ( -2.076 percent), but when UK banks acquire domestic banks, shareholder returns are significant and positive (1.628 percent).

An example of the effect of changes in business practices on stock return can be seen in Hendricks and Singhal (2005). The authors analyzed long-run stock price and risk reactions to supply chain disruptions. The study included 827 disruption announcements made during the 1989-2000 period. The empirical part of the study measured stock price and risk effects one year before the disruption announcement day and two years after. The stocks which were included in the study were obtained from the NYSE. The analysis yielded the following results: the average abnormal return of firms that experienced disruptions was approximately -40 percent; firms need a long time to recover from the negative effects caused by disruptions; the equity risk increases around the announcement day, and in the year after the announcement day the equity risk is 13.50 percent higher than in the year before the announcement day. 
The second group of papers is focused on political events and their effects on stock returns. Białkowski, Gottschalk, and Wisniewski (2008) included 27 OECD countries in their study to evaluate how national elections affect stock market returns and volatility. The sample included 134 elections, in different time spans for each country, depending on data availability (early data from 1980 to end of 2004). Additional variables were included in the model (such as margin of victory, number of parties or population) in order to have more insights into political, institutional, and other factors in the analysis. The results showed that investors are surprised by election results, which means that stock prices react strongly, and this leads to higher volatility as well. Dangol (2008) focused on the effects of unanticipated political events on stock returns of eleven commercial banks in Nepal (in the 2001-2006 period). The author varies the event window length and divides news into bad and good news. The results showed evidence in favor of good news leading to positive abnormal returns and negative news leading to negative abnormal returns. However, these effects are short-lived (2-3 days). Mahmood, Irfan, Iqbal, Kamran, and Ijaz (2014) observe the effects of 50 political events in the period from 1998 to 2013 on the stock market in Pakistan (with 91, 61, and 21 days in the event window). These events include murders of some politicians, wars with India, military takeovers, and similar negative happenings. The authors find that negative political events have negative significant effects on the Karachi Stock Exchange. Chang, Chen, Gupta, and Nguyen (2015) investigated the relationship between economic policy uncertainty and stock prices for seven OECD countries (i.e., Canada, France, Germany, Italy, Spain, United Kingdom, and United States). To analyze the above-mentioned relationship, they used the so-called bootstrap panel causality test. The authors collected monthly data from January 2001 to April 2013 and examined the determinants of stock price variations over time, as well as the connection between stock prices and macroeconomic variables. The results suggested that the relationship between political uncertainty and stock prices is different among the countries in the sample. The largest stock price variations are found in Italy, Canada, and Spain. The authors concluded that UK and US 
economic policy uncertainties have positive effects on stock prices, whereas in Italy and Spain there is a negative link to overall stock price movements. The other countries included in the analysis (Canada, Germany, and France) did not show a relationship between the examined variables. Koulakiotis, Papapanagos, and Papasyriopolos (2016) observed the effects of elections in Greece both on returns and volatility on the Athens Stock Exchange in the 1985-2008 period. The authors included eight political elections in the research. They wanted to explore whether the risk undertaken by investors around election dates leads to higher return compensation. The event study methodology part included 10 pre-event days and 10 post-event days, whilst the risk part of the model was estimated by using several GARCH specifications. The results showed that there are positive abnormal returns before and after the elections, but negative ones on the election day. Moreover, the volatility rises around election dates. Heston and Sinha (2016) observed 900,000 public news stories in the 2004-2006 period to construct a sentiment index based upon neural networks. This enabled the authors to observe the effects of good and bad news on stock returns. The authors concluded that positive news affects stock prices within one week, whilst negative news predicts low stock returns for up to one quarter. Asteriou and Sarantidis (2016) examined the relationship between political instability and stock market returns from 1993 to 2013 using quarterly time series data. They defined stock market returns as the returns of the stock market index and banking index. Data for political events and stock returns were collected for 18 OECD countries. To analyze possible negative effects between political instability and stock market returns they applied exploratory factor analysis, principal components analysis, and the econometric method of GARCH. The overall results showed that political instability has a negative effect on stock returns. But they also found that not all political events included in this study had a negative effect. Some of them are non-significant and some are positive.

Obradović and Tomić (2017) measured the effects of presidential elections in the USA in November 2012 with event study methodology. They included 
85 companies (banks, investment banks, and insurance companies) whose securities are listed on the NYSE. In this study, they covered a six-month period for the estimation part, which started on May 6, 2012. Because of the number of companies included in the index, the authors used the SP 500 Index as a market flow indicator (it covers a larger proportion of the stock market). The authors used a $[-1,+3]$ day event window, where $\tau_{\text {event }}$ (event date) was the day when the presidential elections were held (November 6, 2012). A sufficient number of tests which were conducted confirmed that the election day affected the return flow of the stocks in the sample. Brexit effects were observed in Burdekin, Hughson, and Gu (2017). The authors collected data on 64 different stock exchanges over the world (with the majority from the EU) for the January-June 2016 period in order to observe the effects of Brexit on world markets. The Brexit referendum was used as the event date (June 24, 2016). The results confirmed that the referendum decision to leave the EU had major negative effects on world stock markets, with the greatest effects on the EU markets. Croatia was included in the study as well, with significant negative abnormal returns on June 24 and 25. Irshad (2017) analyzed the relationship between political instability and stock market performance. Events included in the study are strikes, assassinations, riots, demonstrations, government change, and government longevity. Data for these events were collected from Pakistani newspapers and the book Pakistan 58 Years. Stock price data were extracted from Yahoo Finance from 1998 to 2012. The results showed that there is a negative relationship between political instability and stock price returns. This means that the government should reduce events that cause political instability.

In summary, one can draw several conclusions. In the majority of cases, good news causes positive abnormal returns while negative news causes opposite effects. These effects are short-lived, but they provide opportunities to obtain gains or avoid losses on the stock market. 


\section{Methodology}

Event study methodology is well known in the related literature. Thus, we give a brief overview of it, following MacKinlay (1997), Nageswara and Sreejith (2014), Bartholdy, Olson, and Peare (2007), and Kothari and Warner (2007). Denote with $R_{i, t}$ the observed (actual) return of stock $i$ at date $t$, and with $A R_{i, t}$ the abnormal return of stock $i$ at date $t$. The abnormal return is then defined as:

$A R_{i, t}=R_{i, t}-E\left(R_{i, t} \mid X_{t}\right)$,

where $X_{t}$ denotes available information matrix up to date $t . E\left(R_{i, t} \mid X_{t}\right)$ is the return conditioned by the information matrix which the researcher needs to define. The most common assumptions are:

$E\left(R_{i, t} \mid X_{t}\right)=\mu_{i}$,

or

$E\left(R_{i, t} \mid X_{t}\right)=\hat{R}_{i}$,

where $\mu_{i}=1 / T \sum_{i=1}^{T} R_{i, t}$, and $\hat{R}_{i}$ is the estimated return for stock $i$ based upon the market model,

$R_{i}=\alpha_{i}+\beta_{i} r_{M}+\varepsilon_{i}$,

where $r_{M}$ denotes stock market index return. When estimating relation (4), it is assumed that $\varepsilon_{i} \sim N\left(0, \sigma_{\varepsilon_{i}}^{2}\right)$. Next, one has to define the pre-event window for estimating (2) or (4) and the event window for testing the effects of the event on stock return. As can be seen in the review of the previous literature, the event window is usually short. Kothari and Warner (2007) explain that the horizon length of the window has an impact on test properties: short-horizon window based tests are well specified. This means that these tests are powerful (in terms of type II errors and committing them; for more details see Sheskin, 2004). However, they are sensitive to the size of the sample. Since this study uses stocks from an illiquid stock market, it was limited to 30 stocks (please see the next 
section). Bartholdy et al. (2007) focused on sample sizes in event studies and concluded that it is possible to obtain meaningful results with smaller samples but non-parametric tests are preferable.

In order to test the null hypothesis $H_{0}$ "the event did not have any effects on stock returns", we need to calculate the average abnormal return, $\overline{A R}_{\tau}$,

$\overline{A R_{\tau}}=\frac{1}{N} \sum_{i=1}^{N} A R_{i, \tau}$,

with

$\operatorname{var}\left(\overline{A R_{\tau}}\right)=\frac{1}{N^{2}} \sum_{i=1}^{N} \sigma_{\varepsilon_{i}}^{2}$

for each observed date in the event window, $\tau \in\left\{\tau_{\text {start }}, \ldots, \tau_{\text {event }}, \ldots, \tau_{\text {end }}\right\}$, where $N$ denotes the number of observed stocks. Cumulative average abnormal return for each day in the event window, $\overline{C A R_{\tau}}$, is calculated as:

$\overline{C A R}_{\tau}=\sum_{\tau=\tau_{\text {satur }}}^{\tau} \overline{A R}_{\tau}$,

with

$\operatorname{var}\left(\overline{C A R}_{\tau}\right)=\frac{1}{N^{2}} \sum_{i=1}^{N} \operatorname{var}\left(\overline{A R}_{\tau}\right)$.

The test value for each day in the event window is given as

$\theta_{1}=\frac{\overline{C A R}_{\tau}}{\sqrt{\operatorname{var}\left(\overline{C A R}_{\tau}\right)}} \sim N(0,1)$.

Equivalently, we can test whether the average abnormal returns are statistically significant. Thus, we can observe the following hypothesis:

$$
\begin{array}{lll}
H_{0}: \overline{A R}_{\tau}=0 & & H_{0}: \overline{C A R}_{\tau}=0 \\
H_{0}: \overline{A R}_{\tau} \neq 0 & \text { or } & H_{0}: \overline{C A R}_{\tau} \neq 0 .
\end{array}
$$

A non-parametric test can be carried out as well, called the sign test. It is assumed that abnormal returns are independent across stocks. Thus, the expected 
proportion of positive abnormal returns is equal to the proportion of negative ones in the null hypothesis:

$H_{0}: p \leq 0.5$

$H_{0}: p>0.5$,

where $p$ denotes the proportion of positive abnormal returns, $p=P\left(C A R_{i} \geq 0\right)$. The test statistic is given as:

$\theta_{2}=\left(\frac{N^{+}}{N}-0.5\right) \cdot \frac{\sqrt{N}}{0.5} \sim N(0,1)$,

where $N^{+}$denotes the number of stocks with $p=P\left(C A R_{i} \geq 0\right)$. MacKinlay (1997) advises for the test in (10) that $N \geq 30$. So, when there is a smaller number of stocks, as in the empirical part of this study, we focus on the results of the test in (11) since no restrictions are given on number or stocks. Additional robustness can be checked via non-parametric tests which are based upon ranks. The null hypothesis assumes that the median value of a series is equal to the specific value. Here, we choose a value of 0 as it is based on the same proportion in the previous test. Three tests will be reported in the analysis as well: binomial sign test, normal approximation sign test, and Wilcoxson signed rank test. For details see Sheskin (1997).

\section{Empirical Results}

For the purpose of empirically evaluating the effects of the Agrokor case on the Zagreb Stock Exchange, data on 30 stocks were collected for the period from December 31, 2015 to April 28, 2017². The sample includes liquid stocks for which we could obtain the most data in the observed period. Six stocks were from the Agrokor concern. The end date in April 2017 was chosen due to suspension

1 Because we examine specific events in this study, we opted to estimate model (4) beginning with December 2015 in order to exclude the potential effects of ZSE announcements related to changes in the structure of the CROBEX stock market index. Other event study research (see, e.g., Gregoriou, 2011 and references in this study for more details) has found that announcements of restructuring the stock market index cause reactions in stock returns. This is why our sample does not begin as early as it could have. 
of trading in several Agrokor stocks. All of the stocks included in the analysis are shown in the Appendix in Table A1. These stocks were included because they were traded more than 50 percent of the time in the observed period. In that way, more liquid stocks were included in the study so the calculations could be made ${ }^{2}$.

We wanted to test several economic and political events related to Agrokor:

- January 2, 2017 - Moody’s lowered Agrokor's credit rating from B2 to B3 $(\text { economic })^{3}$

- February 24,2017 - Moody’s lowered Agrokor's credit rating again (economic) ${ }^{4}$

- March 14, 2017 - Croatian government and Agrokor's representatives met to discuss problems (political)

- March 30, 2017 - Speaker of the Parliament Božo Petrov filed criminal charges against the Agrokor Management Board (political) ${ }^{6}$

- April 7, 2017 - Lex Agrokor came into force (legislation introduced just for the case of Agrokor, political $)^{7}$

2 The full Excel file with all of the return data series is available upon request for possibilities of replicating the whole analysis done in this study. The list of used stocks is given in the Appendix in Table A1, with percentages of nontrading days. The only exceptions to the 50 percent rule were JMNC and TISK; however, due to those two stocks being in Agrokor's sample, we opted to leave them in order to have more data available in the majority of events.

3 This is perceived as negative news because Moody's (2018a) stated that Agrokor's operating performance had deteriorated and it was not likely that Agrokor would restore credit ratios in line with the requirements for a B2 rating. Other reasons for perceiving this as bad news can be found in the statement available at: https://www. moodys.com/research/Moodys-downgrades-Agrokor-to-B3-outlook-stable--PR_360263.

4 Details on why this is considered bad news can be found in Moody's (2018b) statement available at: https://www. moodys.com/research/Moodys-downgrades-Agrokor-to-Caa1-outlook-negative--PR_364254.

5 This event is perceived as bad news due to statements from key government representatives that the state would not bail out Agrokor.

6 This is perceived as negative news for investors, since the criminal charges are based upon suspicion of having falsified financial statements over the years.

7 This is perceived as negative news due to the interpretations of legal experts; for details see Klepo, Bićanić, and Ivanković (2017). 
- April 10, 2017 - Croatian government appointed Ante Ramljak as extraordinary commissioner for Agrokor (political) ${ }^{8}$

Regardless of our classification of an event as either good or bad news, the sign of CAARs estimated for each group of stocks will show whether some news/event was perceived as good or bad. This is in line with research such as Diamonte, Liew, and Stevens (1996), Erb, Harvey, and Viskanta (1996), Perotti and van Oijen (2001), or Lehkonen and Heimonen (2015); where greater returns are interpreted as investors perceiving lower economic and political risks and vice versa for lower returns. In order to test the research hypotheses of this study, we divided the sample of 30 stocks into two groups: one group (6 stocks) exclusively from Agrokor and the other group (24 stocks) containing other liquid stocks frequently traded on the ZSE. For the pre-event window (year 2016) we estimate equation (4) for every stock and calculate abnormal returns given in (1) for the event window. All of the estimated variance-covariance matrices have been calculated based upon Newey-West (1987) corrections. Based upon previous literature, we have chosen -10 and +10 days window length, which means that with the event date $\tau_{\text {event }}$ the total length of the event window is 21 days. The results are given in Tables 1 and 2 .

By observing Table 1 some conclusions emerge. The events on April 7 and April 10 have been merged into one event, due to those two trading days being consecutively one after another so the days before and after those two events lie upon the same intervals. In Table 1 we test the research hypothesis that negative events regarding Agrokor negatively affected the abnormal returns of Agrokor stocks. It can be seen that the average abnormal returns for the 21-day event window were mostly negative for Agrokor stocks, which was expected. However, not all of the values were statistically significant. The results for the test value of

8 This can be perceived as negative news as in the theory of Stern and Feldman (2004), where government interventions are explained via maximizing personal welfare, calling these types of institutions "too political to fail".

9 Detailed results of the estimation are shown in the Appendix. For each stock we estimated a regression model of (4) with the Newey-West (1987) correction of standard errors due to problems of autocorrelation and/or heteroskedasticity. Since the estimated values of the return series are the only thing important from model (4), they are used in the further analysis, as this is the usual approach in this methodology. 
$\theta_{1}$ do not show effects of the events on January 2, February 24, March 14, and March 30 in 2017 on Agrokor stocks' abnormal returns. The test value of $\theta_{1}$ is statistically significant for the events on April 7 and April 10 for almost every day after the announcement day. But this statement needs to be carefully considered. Since this is a parametric test which includes only six stocks, we focus on the non-parametric test by observing the values of $\theta_{2}$, which is more reliable. It can be seen now that the last three events had a significant effect on Agrokor stocks' return. Moreover, the third event had statistically significant results for almost every day before the event; whereas the fourth event had statistically significant results on all the days after the event. This could be interpreted by assuming that some information was leaking to the investment public before the third event happened and investors perceived it as negative news. A different conclusion arises for the event on March 30. It seems that investors did not anticipate this event; however, they did evaluate it negatively. The negative effect of Agrokorrelated news on Agrokor's stocks can be seen on the April 7 and April 10 events, especially from the second day after the announcement, where almost all the results are significant at the 1 percent significance level. Similarly, the days before the announcement day are significant, but with a lower level of significance.

All of the significant results had negative coefficients, which means that political events had negative effects on stock returns several days before the announcement, as well as several days after the announcement (depending on the observed event). Negative CAARs and the results are in line with previous research, such as Bongini, Nieri, and Pelagatti (2015) and Zanghieri (2017), finding that negative returns are a result of investors observing this as higher costs of those firms due to having to recapitalize - a finding which is often a characteristic of "too big to fail" banks and investment funds (see Cetorelli \& Traina, 2018 for more empirical research in banking). Moreover, as new news accumulated over March and April, it could be said that the chain of events resulted in greater reactions as the weeks passed by. This is why stronger effects were found in later 
events compared to the first ones tested in this study. These results are supported in the Appendix via non-parametric tests (see Tables A8-A11).

Table 2 shows how the events related to Agrokor affected stocks which are listed and frequently traded on the ZSE but do not belong to Agrokor. The majority of the cumulative abnormal returns were positive, which could be interpreted as investors fleeing from Agrokor stocks to these stocks (investors creating price pressures for this second group of stocks). The stock price reaction for these stocks was only statistically significant for the January 2 event on days $t_{+8}$ and $t_{-10}$, which we do not relate to the event. The non-parametric test for the last event resulted in a statistically significant result for the majority of days after the event. This means that the legislation brought on April 7 and the appointment of the new commissioner were the main events affecting both Agrokor and non-Agrokor stocks. Moreover, the non-parametric test results in the Appendix (Tables A4-A7) confirm these conclusions: for the majority of the observed days, non-significant impacts were found in CAARs of non-Agrokor stocks, with the only positive exception of the events in April 2017. It can be concluded that the problems concerning Agrokor mostly did not have a negative impact on stock prices on the ZSE. Also, observing the cumulative abnormal return for all the event days, one can see the CAAR direction changing from negative to positive and vice versa.

CAARs for both groups of stocks are shown in Figures 1 and 2, in order to get a clearer picture of their movements which are described in Tables 1 and 2 . It can be clearly seen that Agrokor stocks had negative (and statistically significant in some cases) CAARs, whilst the opposite was true for other stocks. Events 3 and 5 had the most prominent effects on stock returns. These insights could help to identify the possibilities of forming trading strategies to achieve abnormal returns in the event window. 


\begin{tabular}{|c|c|c|c|c|c|c|c|c|c|c|c|c|c|c|c|c|c|c|c|c|c|c|c|}
\hline 0 & $\sigma^{2}$ & -1 & -1 & $\begin{array}{c}\infty \\
0 \\
i \\
1\end{array}$ & 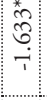 & 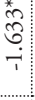 & $\frac{*}{\hat{\sigma}}$ & \begin{tabular}{l}
$*$ \\
\multirow{2}{*}{+} \\
$\mathrm{f}$ \\
$\mathrm{\sim}$
\end{tabular} & & 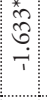 & 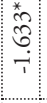 & $\begin{array}{l}0 \\
0 \\
0 \\
0 \\
1\end{array}$ & 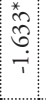 & \begin{tabular}{l}
$*$ \\
$*$ \\
\multirow{2}{*}{} \\
$\stackrel{4}{i}$
\end{tabular} & 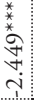 & 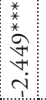 & $\begin{array}{l}* \\
\frac{*}{2} \\
i \\
i\end{array}$ & \begin{tabular}{c}
$*$ \\
$*$ \\
\multirow{2}{*}{} \\
$i$
\end{tabular} & $\begin{array}{l}\frac{*}{*} \\
\frac{f}{f} \\
\frac{f}{i} \\
i\end{array}$ & $\begin{array}{c}0 \\
\infty \\
0 \\
1 \\
1\end{array}$ & 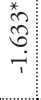 & 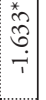 & \\
\hline 党 & $0^{-1}$ & 1 & - & $\begin{array}{l}\infty \\
0 \\
0 \\
1\end{array} \mid$ & $\begin{array}{l}x \\
0 \\
0 \\
1\end{array}$ & $\begin{array}{l}1 \\
\text { L } \\
\vdots \\
i\end{array}$ & $\begin{array}{l}0 \\
0 \\
0\end{array}$ & $\begin{array}{l}\infty \\
\infty \\
1\end{array}$ & $\begin{array}{l}n \\
\hat{o} \\
-1\end{array}$ & $\begin{array}{c}* \\
\infty \\
\stackrel{*}{4} \\
i\end{array}$ & $\frac{1}{6}$ & $\begin{array}{l}\exists \\
i\end{array}$ & $\begin{array}{l}* \\
2 \\
\stackrel{2}{2} \\
\\
1\end{array}$ & $\begin{array}{l}* \\
\stackrel{*}{*} \\
\stackrel{4}{i}\end{array}$ & : & 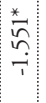 & $\frac{*}{\infty} \frac{\infty}{\frac{2}{i}}$ & $\frac{*}{\circ}$ & 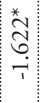 & $\frac{1}{0}$ & \begin{tabular}{|c|c|}
5 \\
0 \\
0 \\
1
\end{tabular} & $\begin{array}{l}\infty \\
2 \\
0 \\
0 \\
1\end{array}$ & \\
\hline & 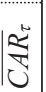 & $\infty$ & - & $\begin{array}{c}\infty \\
0 \\
0 \\
1\end{array} \mid$ & $\frac{9}{\hat{T}}$ & 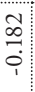 & $\frac{\infty}{2}$ & $\begin{array}{l}\stackrel{0}{2} \\
\grave{1} \\
1\end{array}$ & 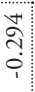 & $\begin{array}{c}\frac{n}{\infty} \\
\vdots \\
1\end{array}$ & $\begin{array}{c}\hat{n} \\
\hat{i}\end{array}$ & $\begin{array}{c}\infty \\
2 \\
i \\
1\end{array}$ & $\begin{array}{l}\tilde{D} \\
\grave{1} \\
\grave{1}\end{array}$ & $\begin{array}{c}\frac{m}{i} \\
\grave{1}\end{array}$ & $\begin{array}{l}\overrightarrow{\hat{N}} \\
\dot{0} \\
i\end{array}$ & 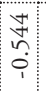 & के & $\begin{array}{l}\vec{\infty} \\
\stackrel{2}{0} \\
i\end{array}$ & $\begin{array}{l}\grave{2} \\
\grave{o} \\
i\end{array}$ & $\dot{t}^{+}$ & के & $\begin{array}{c}+ \\
0 \\
0 \\
1 \\
1\end{array}$ & \\
\hline \multirow{3}{*}{ 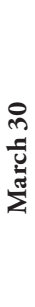 } & $\theta^{N}$ & Oे & $\begin{array}{l}\overrightarrow{0} \\
\stackrel{0}{0} \\
0 \\
0\end{array}$ & : & $\begin{array}{c}0 \\
\infty \\
0 \\
1\end{array}$ & 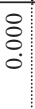 & $\begin{array}{c}0 \\
\infty \\
0 \\
1\end{array}$ & $\begin{array}{c}0 \\
\infty \\
0 \\
1\end{array}$ & 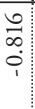 & $\mid \begin{array}{l}0 \\
\infty \\
i \\
1\end{array}$ & : & 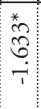 & $\begin{array}{c}* \\
\tilde{x} \\
i \\
i\end{array}$ & $\begin{array}{c}* \\
\hat{\sigma} \\
\dot{\sigma} \\
\dot{1}\end{array}$ & 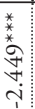 & 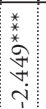 & $\begin{array}{l}* \\
6 \\
6 \\
i \\
i\end{array}$ & 17 & $1-$ & - & -1 & 1 & \\
\hline & $0^{-1}$ & $\begin{array}{l}n \\
0 \\
0 \\
1\end{array}$ & 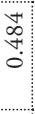 & $\begin{array}{l}\vec{n} \\
0\end{array}$ & : & 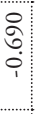 & $\begin{array}{l}\overline{0} \\
\\
\end{array}$ & $\begin{array}{l}\overrightarrow{7} \\
\vdots \\
i\end{array}$ & 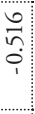 & $\begin{array}{c}\infty \\
0 \\
0 \\
1\end{array}$ & $\frac{\hat{2}}{\grave{i}}$ & $\frac{\vec{A}}{\vec{T}}$ & 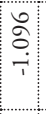 & $\begin{array}{c}\infty \\
\infty \\
0 \\
1\end{array}$ & $\begin{array}{l}\vec{b} \\
\stackrel{\leftrightarrow}{1}\end{array}$ & 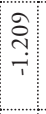 & 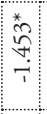 & $1-$ & - & - & 1 & - & \\
\hline & | & $\begin{array}{l}2 \\
0 \\
\grave{1}\end{array}$ & $\begin{array}{l}\infty \\
\stackrel{0}{\circ} \\
\stackrel{\circ}{\circ}\end{array}$ & $\begin{array}{l}m \\
0 \\
0\end{array}$ & $\begin{array}{l}f \\
0 \\
0 \\
1 \\
1\end{array}$ & $\begin{array}{l}n \\
0 \\
0 \\
0 \\
\vdots \\
1\end{array}$ & $\begin{array}{l}\hat{T} \\
0 \\
1\end{array}$ & ț & $\begin{array}{l}0 \\
0 \\
0 \\
\vdots \\
i\end{array}$ & $\frac{m}{2}$ & $\frac{0}{i}$ & $\begin{array}{l}\overrightarrow{\check{N}} \\
\grave{\varphi}\end{array}$ & $\frac{n}{\hat{n}}$ & $\begin{array}{l}0 \\
2 \\
i \\
1\end{array}$ & 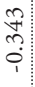 & $\begin{array}{l}0 \\
0 \\
0 \\
1 \\
1\end{array}$ & $\begin{array}{l}\infty \\
0 \\
0 \\
i \\
1\end{array}$ & - & - & - & -1 & - & \\
\hline \multirow{3}{*}{ 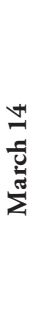 } & $\theta^{2}$ & 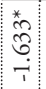 & $\begin{array}{l}0 \\
\stackrel{0}{0} \\
\dot{i} \\
\end{array}$ & $\begin{array}{c}* \\
\tilde{x} \\
i \\
i\end{array}$ & क्ष & 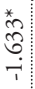 & $\begin{array}{c}0 \\
\infty \\
\\
1\end{array}$ & $\frac{*}{\infty}$ & 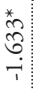 & \begin{tabular}{|c|}
0 \\
$\infty$ \\
$i$ \\
1
\end{tabular} & $\begin{array}{l}0 \\
\infty \\
i \\
i\end{array}$ & $\begin{array}{c}0 \\
\infty \\
0 \\
1\end{array}$ & $\begin{array}{l}0 \\
0 \\
0 \\
0\end{array}$ & \begin{tabular}{|c|}
0 \\
$\infty$ \\
0 \\
1
\end{tabular} & 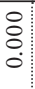 & $\begin{array}{l}0 \\
0 \\
0 \\
0\end{array}$ & \begin{tabular}{|l}
0 \\
$\infty$ \\
0 \\
1
\end{tabular} & $\begin{array}{l}8 \\
0 \\
0\end{array}$ & $\begin{array}{l}0 \\
0 \\
0 \\
0\end{array}$ & 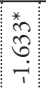 & ஸ̂. & $\begin{array}{c}0 \\
\infty \\
0 \\
1\end{array}$ & \\
\hline & $0^{-1}$ & $\begin{array}{l}1 \\
\infty \\
\hat{i}\end{array}$ & $\begin{array}{l}0 \\
\hat{\sigma} \\
\vdots \\
\vdots\end{array}$ & $\begin{array}{c}\infty \\
\grave{2} \\
1\end{array}$ & $\frac{1}{4}$ & $\begin{array}{l}8 \\
\text { : } \\
\vdots \\
i\end{array}$ & $\begin{array}{l}\infty \\
\\
0 \\
1\end{array}$ & $\begin{array}{c}0 \\
0 \\
0 \\
1\end{array}$ & $\begin{array}{l}\text { ते } \\
\text { s. } \\
\text { 1 }\end{array}$ & $\frac{\infty}{0}$ & $\frac{\hat{n}}{\hat{i}}$ & $\begin{array}{l}1 \\
5 \\
i \\
i\end{array}$ & $\begin{array}{l}\hat{R} \\
\hat{1}\end{array}$ & 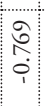 & $\begin{array}{l}\hat{n} \\
\hat{\sigma} \\
0\end{array}$ & $\begin{array}{l}0 \\
0 \\
0 \\
1\end{array}$ & $\frac{0}{2}$ & $\begin{array}{c}\infty \\
\frac{n}{1}\end{array}$ & $\begin{array}{c}\infty \\
\grave{Q} \\
1\end{array}$ & $\begin{array}{c}\hat{x} \\
\infty \\
i \\
i\end{array}$ & 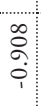 & \begin{tabular}{c}
$\tilde{\Delta}$ \\
\hdashline$\rightarrow-1$
\end{tabular} & \\
\hline & $\mid$ & $\begin{array}{l}\hat{D} \\
0 \\
i\end{array}$ & $\begin{array}{l}0 \\
\text { ô. } \\
0\end{array}$ & $\begin{array}{l}0 \\
0 \\
0 \\
1\end{array}$ & $\begin{array}{l}\infty \\
0 \\
0 \\
1\end{array}$ & $\begin{array}{l}\text { r̂. } \\
\text { ô. } \\
\vdots \\
1\end{array}$ & $\begin{array}{c}m \\
0 \\
1\end{array}$ & $\begin{array}{l}\vec{b} \\
0 \\
i\end{array}$ & $\begin{array}{l}n \\
\tilde{o} \\
\dot{i}\end{array}$ & $\begin{array}{l}0 \\
0 \\
0\end{array}$ & $\begin{array}{l}m \\
0 \\
i\end{array}$ & $\begin{array}{l}1 \\
\vdots \\
0 \\
1\end{array}$ & $\begin{array}{c}0 \\
7 \\
1 \\
1\end{array}$ & $\begin{array}{l}\text { A } \\
0 \\
i\end{array}$ & 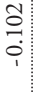 & $\begin{array}{l}1 \\
\\
1\end{array}$ & $\frac{1}{6}$ & $\begin{array}{l}n \\
\hat{n} \\
\vdots \\
1\end{array} \mid$ & $\begin{array}{l}2 \\
0 \\
\end{array}$ & $\begin{array}{c}\infty \\
0 \\
0 \\
1 \\
1\end{array}$ & $\begin{array}{l}\text { Cे } \\
\text { in }\end{array}$ & $\begin{array}{c}\infty \\
\tilde{n} \\
0 \\
1\end{array}$ & \\
\hline \multirow{3}{*}{ 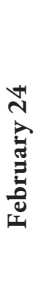 } & $\theta^{2}$ & 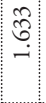 & 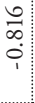 & 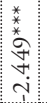 & $\stackrel{*}{\stackrel{*}{6}}$ & $\begin{array}{l}0 \\
0 \\
0 \\
i \\
i\end{array}$ & $\begin{array}{l}0 \\
0 \\
0\end{array}$ & $\stackrel{0}{0}$ & 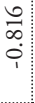 & $\begin{array}{l}0 \\
\infty \\
1 \\
1\end{array}$ & $\begin{array}{l}0 \\
\infty \\
\\
1\end{array}$ & Oे & $\begin{array}{l}0 \\
\infty \\
0 \\
1\end{array}$ & $\begin{array}{l}0 \\
\infty \\
0 \\
1\end{array}$ & 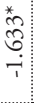 & $\begin{array}{c}0 \\
0 \\
0 \\
1\end{array}$ & $\begin{array}{l}0 \\
\infty \\
\\
1\end{array}$ & ${ }_{\tilde{\omega}}^{*}$ & $\begin{array}{l}0 \\
0 \\
0 \\
i\end{array}$ & $\begin{array}{l}0 \\
0 \\
0\end{array}$ & $\begin{array}{ll}1 \\
0 \\
0 \\
1\end{array}$ & $\begin{array}{l}0 \\
\infty \\
0 \\
0 \\
1\end{array}$ & \\
\hline & $0^{-1}$ & So & 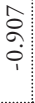 & \begin{tabular}{c}
$\infty$ \\
\hdashline \\
$i$
\end{tabular} \mid & $\begin{array}{l}2 \\
0 \\
i\end{array}$ & $\begin{array}{l}0 \\
\text { â } \\
\vdots \\
1\end{array}$ & $\frac{1}{1}$ & $\frac{1}{2}$ & $\begin{array}{l}\stackrel{\infty}{+}, \\
\stackrel{0}{0}\end{array}$ & $\frac{+4}{0}$ & $\frac{1}{0}$ & ते & $\begin{array}{l}\infty \\
0 \\
0\end{array}$ & $\begin{array}{l}\text { Dेt } \\
\text { on }\end{array}$ & 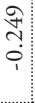 & 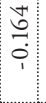 & $\begin{array}{l}\hat{1} \\
\text { Q }\end{array}$ & $\begin{array}{c}\hat{1} \\
\text { के }\end{array}$ & $\begin{array}{l}m \\
0 \\
\end{array}$ & $\stackrel{0}{0}$ & $\begin{array}{c}0 \\
0 \\
\end{array}$ & $\hat{\tilde{o}}$ & \\
\hline & $\mid$ & ồ & $\begin{array}{l}\vec{n} \\
\vdots \\
i\end{array}$ & $\begin{array}{l}\infty \\
0 \\
0 \\
i\end{array} \mid$ & $\begin{array}{l}0 \\
0 \\
0 \\
i\end{array}$ & $\begin{array}{l}\hat{a} \\
\hat{\sigma} \\
\hat{i}\end{array}$ & $\frac{1}{0}$ & $\frac{1}{0}$ & $\begin{array}{l}\hat{a} \\
\text { o. }\end{array}$ & $\frac{1}{0}$ & के & $\begin{array}{c}1 \\
\vdots \\
0 \\
0\end{array}$ & $\begin{array}{c}n \\
0 \\
0 \\
1\end{array} \mid$ & $\begin{array}{c}1 \\
0 \\
0 \\
1\end{array}$ & $\begin{array}{l}\text { ô. } \\
\text { ô. } \\
1\end{array}$ & $\begin{array}{l}\overrightarrow{\widehat{D}} \\
\dot{0} \\
1\end{array}$ & $\begin{array}{l}\hat{\beta} \\
\hat{i}\end{array}$ & $\begin{array}{l}\hat{\hat{o}} \\
\dot{1}\end{array}$ & $\begin{array}{c}\infty \\
0 \\
\dot{\varphi}\end{array}$ & $\begin{array}{l}1 \\
0 \\
\vdots \\
i\end{array}$ & $\begin{array}{l}0 \\
0 \\
0 \\
1\end{array} \mid$ & $\begin{array}{l}n \\
0 \\
0 \\
0\end{array}$ & \\
\hline \multirow{3}{*}{ : } & $\theta^{2}$ & $\begin{array}{l}\infty \\
\infty \\
\\
1\end{array}$ & & $\begin{array}{c}\infty \\
\infty \\
i \\
i\end{array}$ & $\begin{array}{l}0 \\
\infty \\
\\
i\end{array}$ & $\begin{array}{l}0 \\
0 \\
0\end{array}$ & $\begin{array}{l}\hat{b} \\
\frac{1}{4}\end{array}$ & $\begin{array}{c}* \\
\hat{\sigma} \\
i\end{array}$ & 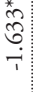 & $\begin{array}{c}\infty \\
0 \\
\\
i\end{array}$ & $\begin{array}{l}\infty \\
\infty \\
\\
i\end{array}$ & $\begin{array}{l}0 \\
\infty \\
\\
i\end{array}$ & $\begin{array}{l}* \\
\hat{\sigma} \\
1\end{array}$ & $\begin{array}{l}0 \\
0 \\
0 \\
0\end{array}$ & 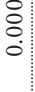 & $\stackrel{\hat{\sigma}}{*}$ & $\begin{array}{l}\infty \\
\infty \\
\\
1\end{array}$ & $\begin{array}{c}0 \\
\infty \\
0 \\
i\end{array}$ & $\begin{array}{l}\infty \\
0 \\
\\
\end{array}$ & Oे & : & $\begin{array}{l}0 \\
0 \\
0 \\
0\end{array}$ & \\
\hline & $0^{-1}$ & $\begin{array}{l}0 \\
i \\
i \\
1\end{array}$ & 范: & 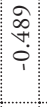 & $\begin{array}{l}1 \\
0 \\
0\end{array}$ & 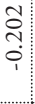 & $\stackrel{\infty}{2}:$ & $\begin{array}{l}m \\
0 \\
i \\
i\end{array}$ & $\begin{array}{l}\vec{m} \\
\stackrel{0}{i} \\
i\end{array}$ & \begin{tabular}{c}
0 \\
\hdashline \\
1 \\
1
\end{tabular} & $\begin{array}{l}1 \\
0 \\
0 \\
1\end{array}$ & $\begin{array}{l}1 \\
0 \\
0 \\
1\end{array}$ & $\begin{array}{c}p \\
0 \\
0\end{array} \mid$ & $\frac{0}{0}$ & $\stackrel{\infty}{\overrightarrow{0}}$ & $\frac{1}{2}$ & $\begin{array}{l}n \\
\hat{0} \\
0 \\
1\end{array}$ & $\begin{array}{l}1 \\
0 \\
0 \\
0\end{array}$ & $\begin{array}{c}1 \\
0 \\
0 \\
i\end{array}$ & $\begin{array}{c}\vec{\delta} \\
0\end{array}$ & वे & $\frac{\cong}{\stackrel{0}{0}}$ & t \\
\hline & $\mid$ & 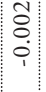 & $\begin{array}{l}\text { â. } \\
\vdots \\
\vdots\end{array}$ & $\begin{array}{c}m \\
0 \\
i\end{array}$ & : & $\begin{array}{l}0 \\
: \\
0 \\
\vdots \\
\vdots\end{array}$ & $\begin{array}{l}1 \\
0 \\
\dot{1}\end{array}$ & $\begin{array}{l}m \\
0 \\
1\end{array}$ & $\begin{array}{l}0 \\
: \\
\vdots \\
\vdots\end{array}$ & $\begin{array}{c}\bar{b} \\
0 \\
\end{array}$ & $\begin{array}{l}\dot{1} \\
0 \\
\dot{i}\end{array}$ & $\begin{array}{l}1 \\
8 \\
0 \\
1\end{array}$ & $\stackrel{+}{\circ}$ & $\begin{array}{l}1 \\
0 \\
0\end{array}$ & $\begin{array}{l}\dot{\partial} \\
\dot{\circ} \\
\dot{\circ}\end{array}$ & $\begin{array}{l}0 \\
0 \\
0 \\
1\end{array}$ & ồ & : & $\begin{array}{l}0 \\
0 \\
i\end{array}$ & $\begin{array}{l}m \\
0 \\
0\end{array}$ & & $\begin{array}{l}0 \\
0 \\
0\end{array}$ & si \\
\hline & & 19 & ఢi & 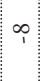 & 1 & יו: & 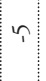 & +1 & $r$ & $T_{0}$ & 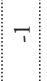 & 0 & 7 & $\mathcal{F}$ & + & + & $\stackrel{n}{+}$ & 10 & + & $\stackrel{\infty}{+}$ & $\uparrow$ & $\frac{9}{7}$ & 。 \\
\hline
\end{tabular}




\begin{tabular}{|c|c|c|c|c|c|c|c|c|c|c|c|c|c|c|c|c|c|c|c|c|c|c|c|}
\hline & $\sigma^{2}$ & - & & $\stackrel{*}{\stackrel{*}{\infty}}$ & ֶָ. & $\begin{array}{l}0 \\
0 \\
0 \\
0\end{array}$ & 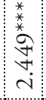 & 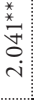 & & 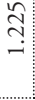 & הి & & ત્ત & 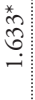 & 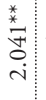 & \begin{tabular}{l} 
*. \\
\multirow{2}{*}{} \\
i
\end{tabular} & $\begin{array}{c}0 \\
\infty \\
0 \\
0\end{array}$ & $\begin{array}{l}\frac{*}{*} \\
\stackrel{5}{5} \\
\text { in: }\end{array}$ & $\begin{array}{l}\stackrel{*}{*} \\
\stackrel{+}{+} \\
\stackrel{i}{i}\end{array}$ & గ̂̉ & 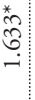 & & \\
\hline ( & $0^{-}$ & - & - & $\begin{array}{l}\vec{t} \\
\stackrel{1}{0} \\
0\end{array}$ & $\begin{array}{l}\bar{n} \\
\dot{o}\end{array}$ & $\begin{array}{l}0 \\
0 \\
0 \\
0\end{array}$ & $\frac{\Xi}{0}$ & $\begin{array}{l}\stackrel{f}{f} \\
\stackrel{\circ}{\circ}\end{array}$ & $\begin{array}{c}\vec{\delta} \\
0\end{array}$ & $\begin{array}{l}0 \\
\dot{0} \\
\dot{0}\end{array}$ & $\begin{array}{l}\hat{\delta} \\
\text { oे }\end{array}$ & $\begin{array}{l}\text { Dे } \\
0\end{array}$ & $\begin{array}{l}0 \\
\dot{o} \\
\vdots \\
0\end{array}$ & $\begin{array}{l}n \\
\hat{o} \\
0 \\
0\end{array}$ & {$\left[\begin{array}{l}\infty \\
0 \\
0\end{array}\right]$} & 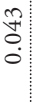 & $\begin{array}{l}+4 \\
0 \\
0\end{array}$ & \begin{tabular}{l}
$\infty$ \\
\multirow{0}{0}{} \\
$\vdots$ \\
0
\end{tabular} & $\begin{array}{l}\stackrel{m}{f}, \\
\stackrel{0}{0}\end{array}$ & $\begin{array}{l}: \\
: \\
:\end{array}$ & 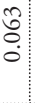 & & \\
\hline & త্ & - & 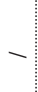 & $\begin{array}{l}0 \\
0 \\
0 \\
0 \\
0\end{array}$ & $\begin{array}{l}\hat{s} \\
\text { ò } \\
0\end{array}$ & $\begin{array}{l}1 \\
0 \\
0 \\
0 \\
1\end{array}$ & $\frac{1}{2}$ & $\begin{array}{l}\hat{U} \\
\stackrel{1}{0} \\
\dot{0} \\
\dot{0}\end{array}$ & $\begin{array}{l}0 \\
\grave{b} \\
0\end{array}$ & $\begin{array}{l}\text { oे } \\
\dot{0} \\
\dot{0}\end{array}$ & $\begin{array}{l}\hat{o} \\
o \\
0 \\
0\end{array}$ & $\begin{array}{l}\infty \\
\grave{b} \\
0 \\
0\end{array}$ & $\begin{array}{l}\text { in } \\
\text { - } \\
0 \\
0\end{array}$ & $\begin{array}{l}\stackrel{1}{1} \\
\vdots \\
\vdots \\
\vdots\end{array}$ & $\begin{array}{l}\infty \\
\stackrel{\infty}{0} \\
0 \\
0\end{array}$ & 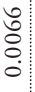 & $\begin{array}{l}0 \\
\hat{b} \\
0 \\
0\end{array}$ & $\begin{array}{l}\widehat{\hat{\sigma}} \\
\vdots \\
0\end{array}$ & $\begin{array}{l}\mathbb{\hat { \sigma }} \\
0 \\
0 \\
0\end{array}$ & $\begin{array}{l}\stackrel{\circ}{\circ} \\
\stackrel{\circ}{\circ} \\
\circ\end{array}$ & $\begin{array}{l}\hat{b} \\
\stackrel{0}{b} \\
\dot{0}\end{array}$ & & \\
\hline \multirow{3}{*}{ ले } & $\theta^{2}$ & $\stackrel{8}{\circ}$ & $\begin{array}{l}\infty \\
0 \\
0 \\
1\end{array}$ & $\begin{array}{c}1 \\
\frac{1}{1} \\
\frac{1}{1}\end{array}$ & $\begin{array}{l}\overrightarrow{0} \\
\stackrel{0}{\infty} \\
\dot{0}\end{array}$ & 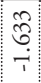 & $\begin{array}{c}0 \\
0 \\
0 \\
0\end{array}$ & $\begin{array}{l}0 \\
\stackrel{0}{0} \\
\vdots \\
0\end{array}$ & $\begin{array}{l}0 \\
0 \\
0\end{array}$ & $\begin{array}{l}0 \\
0 \\
0 \\
0\end{array}$ & 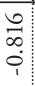 & $\stackrel{\infty}{\circ}$ & $\begin{array}{l}\dot{a} \\
\vdots \\
\circ\end{array}$ & तु & 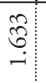 & ֶָ̃ & $\begin{array}{c}0 \\
\infty \\
0 \\
0\end{array}$ & - & - & - & -1 & 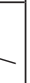 & \\
\hline & $0^{-1}$ & $\stackrel{\infty}{0}_{0}^{\infty}$ & $\begin{array}{l}0 \\
0 \\
0 \\
0\end{array}$ & $\begin{array}{c}0 \\
0 \\
0\end{array}$ & 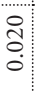 & $\begin{array}{c}5 \\
i \\
i\end{array}$ & $\begin{array}{l}0 \\
\dot{b} \\
i\end{array}$ & $\begin{array}{l}\text { कैl } \\
\text { ol }\end{array}$ & $\stackrel{\infty}{\stackrel{\infty}{0},}$ & $\begin{array}{l}\hat{\infty} \\
0 \\
0\end{array}$ & \begin{tabular}{l}
$\mathscr{\infty}$ \\
$\stackrel{0}{0}$ \\
\hdashline
\end{tabular} & $\left(\begin{array}{l}0 \\
0\end{array}\right.$ & $\begin{array}{l}0 \\
\vdots \\
:\end{array}$ & $\begin{array}{l}\stackrel{\circ}{9} \\
\stackrel{\circ}{\circ}\end{array}$ & $\frac{\hat{b}}{0}$ & 它 & $\begin{array}{l}0 \\
\hat{o} \\
0\end{array}$ & - & - & - & -1 & - & \\
\hline & $\mid$ & ô & 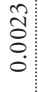 & $\begin{array}{l}\hat{n} \\
0 \\
0 \\
1\end{array}$ & 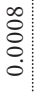 & $\begin{array}{l}1 \\
0 \\
0 \\
0 \\
0\end{array}$ & $\begin{array}{l}0 \\
0 \\
0 \\
1\end{array}$ & $\begin{array}{l}c \\
\text { ô } \\
0 \\
0\end{array}$ & $\begin{array}{l}0 \\
0 \\
0 \\
0\end{array}$ & $\begin{array}{l}{ }^{+} \\
\vdots \\
\vdots \\
\vdots\end{array}$ & $\begin{array}{l}\stackrel{0}{n} \\
\vdots \\
0 \\
0\end{array}$ & $\begin{array}{l}\bar{\partial} \\
\grave{0} \\
0\end{array}$ & $\begin{array}{l}\hat{o} \\
\dot{0} \\
\dot{0}\end{array}$ & 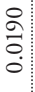 & $\begin{array}{l}\overrightarrow{\tilde{\delta}} \\
0 \\
0\end{array}$ & $\begin{array}{l}0 \\
\stackrel{0}{0} \\
\vdots \\
\vdots\end{array}$ & 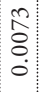 & - & - & -1 & - & - & \\
\hline \multirow{3}{*}{ 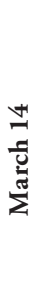 } & $\sigma^{2}$ & 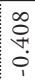 & $\begin{array}{c}0 \\
\infty \\
0 \\
1\end{array}$ & $\begin{array}{l}0 \\
\infty \\
0\end{array}$ & $\begin{array}{c}\vec{v} \\
\overrightarrow{0} \\
0 \\
0\end{array}$ & $\begin{array}{l}0 \\
\infty \\
0 \\
0\end{array}$ & 8 & $\begin{array}{l}\stackrel{8}{\circ} \\
\vdots\end{array}$ & : & $\begin{array}{l}\infty \\
\vdots \\
\vdots \\
0\end{array}$ & $\begin{array}{l}\dot{0} \\
\vdots \\
\vdots\end{array}$ & $\begin{array}{c}\overrightarrow{0} \\
0 \\
0 \\
0\end{array} \mid$ & $\begin{array}{l}\infty \\
0 \\
0 \\
0 \\
0\end{array}$ & $\begin{array}{l}\infty \\
\stackrel{\infty}{o} \\
0 \\
0\end{array}$ & $\begin{array}{l}\infty \\
0 \\
0 \\
0\end{array}$ & $\begin{array}{l}\infty \\
\stackrel{\infty}{0} \\
\vdots \\
0\end{array}$ & \begin{tabular}{|c|} 
\\
0 \\
0 \\
0
\end{tabular} \mid & $\begin{array}{l}0 \\
0 \\
0\end{array}$ & 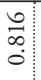 & 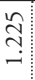 & 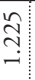 & $\begin{array}{l}0 \\
\vdots \\
0 \\
0\end{array}$ & \\
\hline & $0^{-}$ & $\overbrace{\infty}^{\infty}$ & $\begin{array}{l}\alpha \\
\vdots \\
0 \\
1\end{array}$ & $\frac{n}{0}$ & 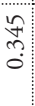 & $\frac{0}{7}$ & o & 筫 & $\begin{array}{c}\infty \\
\infty \\
\infty \\
0\end{array}$ & ๙ิ & क̂ & के & $\begin{array}{c}\hat{n} \\
\tilde{o}\end{array}$ & 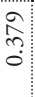 & $\begin{array}{l}\hat{0} \\
2\end{array}$ & 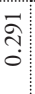 & $\stackrel{m}{\grave{2}}$ & $\begin{array}{l}\text { ה̃ } \\
\text { ปn }\end{array}$ & $\begin{array}{l}\tilde{o} \\
\text { ปे }\end{array}$ & $\begin{array}{l}m \\
\stackrel{m}{o} \\
o\end{array}$ & $\begin{array}{c}\text { ñ. } \\
\text { s. } \\
0\end{array}$ & 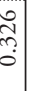 & \\
\hline & $\left.\right|_{0} ^{2}$ & $\begin{array}{l}\infty \\
\stackrel{0}{0} \\
0 \\
\end{array}$ & $\begin{array}{c}0 \\
0 \\
0 \\
1\end{array}$ & $\begin{array}{l}8 \\
0 \\
0\end{array}$ & $\begin{array}{l}\vec{\Delta} \\
\vec{s} \\
\dot{0} \\
\end{array}$ & $\begin{array}{c}m \\
\infty \\
\tilde{d} \\
\dot{0}\end{array}$ & $\begin{array}{l}0 \\
\vdots \\
0 \\
0\end{array}$ & 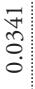 & $\begin{array}{c}\tilde{D} \\
\infty \\
0 \\
0\end{array}$ & $\begin{array}{l}\text { ô } \\
\text { ஜ̊ } \\
0\end{array}$ & $\begin{array}{l}\text { ते } \\
\hat{s} \\
\vdots \\
0\end{array}$ & $\begin{array}{c}\stackrel{0}{\infty} \\
\stackrel{0}{0} \\
0\end{array}$ & $\begin{array}{l}+ \\
0 \\
0 \\
0 \\
0\end{array}$ & $\begin{array}{l}\vec{\beta} \\
\text { } \\
0 \\
0\end{array}$ & $\begin{array}{c}\hat{n} \\
0 \\
0 \\
0\end{array}$ & 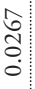 & $\begin{array}{c}\frac{m}{\gamma} \\
\dot{0}\end{array}$ & 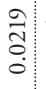 & 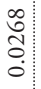 & $\begin{array}{l}\hat{\tilde{o}} \\
\hat{\delta} \\
\dot{\delta}\end{array}$ & 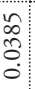 & 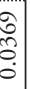 & \\
\hline \multirow{3}{*}{$\Xi$} & $\theta^{2}$ & $\stackrel{\infty}{6}$ & $\begin{array}{l}\infty \\
0 \\
+ \\
0\end{array}$ & $\begin{array}{l}0 \\
\infty \\
0 \\
0\end{array}$ & ઝુర్తి & $\begin{array}{c}0 \\
\infty \\
0\end{array}$ & $\begin{array}{c}0 \\
\infty \\
0\end{array}$ & 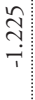 & $\begin{array}{l}\infty \\
0 \\
0 \\
1\end{array} \mid$ & $\begin{array}{l}0 \\
0 \\
0 \\
0\end{array}$ & $\begin{array}{l}\infty \\
\stackrel{0}{+} \\
\vdots \\
1\end{array}$ & $\frac{n}{\stackrel{1}{4}}$ & $\begin{array}{l}0 \\
0 \\
+ \\
0 \\
1\end{array}$ & $\begin{array}{l}0 \\
\stackrel{0}{0} \\
\dot{i}\end{array}$ & 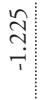 & $\begin{array}{l}\dot{B}, 1 \\
\vdots \\
0\end{array}$ & $\begin{array}{l}0 \\
0 \\
0\end{array}$ & $\begin{array}{l}\infty \\
0 \\
+ \\
0\end{array}$ & $\left.\begin{array}{l}\infty \\
0 \\
0 \\
1 \\
1\end{array}\right]$ & $\begin{array}{l}\stackrel{\circ}{\circ}: \\
\circ\end{array}$ & $\begin{array}{l}\stackrel{0}{0} \\
\vdots \\
0\end{array}$ & $\begin{array}{l}0 \\
0 \\
0 \\
0 \\
0\end{array}$ & \\
\hline & $0^{-}$ & $\frac{\hat{O}}{0}$ & $\begin{array}{l}n \\
\hat{o} \\
\dot{0}\end{array}$ & 官 & 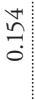 & $\begin{array}{c}\infty \\
\infty \\
0\end{array}$ & $\frac{\partial}{0}$ & $\begin{array}{l}\hat{\hat{o}} \\
0 \\
\hat{i}\end{array}$ & $\begin{array}{l}f \\
0 \\
i\end{array}$ & $\begin{array}{c}f \\
\\
i\end{array}$ & 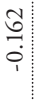 & $\begin{array}{c}0 \\
\text { in } \\
i\end{array}$ & $\frac{a}{\grave{1}}$ & $\begin{array}{l}0 \\
\text { on } \\
\vdots \\
i \\
1\end{array}$ & गे. & $\begin{array}{l}0 \\
0 \\
0 \\
i \\
1\end{array}$ & $\begin{array}{c}\infty \\
0 \\
0 \\
0\end{array} \mid$ & $\begin{array}{l}\hat{\alpha} \\
\hat{o}\end{array}$ & $\begin{array}{l}n \\
\stackrel{0}{0}\end{array}$ & $\begin{array}{l}\stackrel{+}{+} \\
0\end{array}$ & $\begin{array}{l}\hat{\partial} \\
\text { oे }\end{array}$ & $\begin{array}{l}\stackrel{0}{0} \\
0 \\
0\end{array}$ & \\
\hline & | & $\frac{\infty}{8}$ & $\begin{array}{l}1 \\
0 \\
0 \\
0 \\
0\end{array}$ & $\begin{array}{l}1 \\
0 \\
0 \\
0 \\
0\end{array}$ & $\begin{array}{l}0 \\
0 \\
0 \\
0 \\
0\end{array}$ & $\begin{array}{c}0 \\
0 \\
0 \\
0\end{array}$ & $\begin{array}{l}0 \\
0 \\
0 \\
0\end{array}$ & 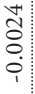 & $\begin{array}{l}\grave{D} \\
\grave{Q} \\
\grave{i}\end{array}$ & $\begin{array}{l}+ \\
0 \\
\vdots \\
\vdots \\
1\end{array}$ & $\begin{array}{l}\text { d. } \\
\text { on } \\
\vdots \\
i\end{array}$ & $\begin{array}{l}\infty \\
\stackrel{0}{0} \\
\grave{1}\end{array}$ & 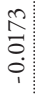 & 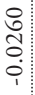 & $\begin{array}{c}\hat{0} \\
\hat{0} \\
\dot{1}\end{array}$ & 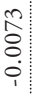 & 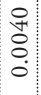 & $\begin{array}{l}0 \\
\vdots \\
0 \\
0 \\
0\end{array}$ & $\begin{array}{l}\tilde{n} \\
\vdots \\
0\end{array}$ & 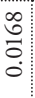 & 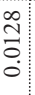 & 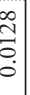 & \\
\hline \multirow{3}{*}{ 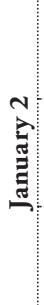 } & $\theta^{2}$ & 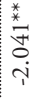 & $\begin{array}{c}0 \\
\infty \\
0 \\
1\end{array}$ & $\frac{2}{2}$ & \begin{tabular}{l}
0 \\
\multirow{0}{0}{} \\
0 \\
1
\end{tabular} & $\begin{array}{l}0 \\
\infty \\
0 \\
1\end{array}$ & $\begin{array}{l}0 \\
\infty \\
0 \\
1\end{array}$ & $\begin{array}{l}0 \\
\stackrel{0}{1} \\
\vdots \\
1\end{array}$ & $\begin{array}{l}\infty \\
0 \\
0 \\
1\end{array}$ & $\begin{array}{l}0 \\
0 \\
0 \\
0\end{array}$ & $\begin{array}{l}\infty \\
\stackrel{0}{+} \\
0\end{array}$ & $\begin{array}{l}0 \\
\infty \\
\end{array}$ & $\begin{array}{l}: \\
: \\
:\end{array}$ & $\begin{array}{l}\infty \\
\stackrel{0}{+} \\
0\end{array}$ & $\left.\mid \begin{array}{c}\infty \\
0 \\
0 \\
1\end{array}\right]$ & 足 & $\begin{array}{c}0 \\
\infty \\
0 \\
1\end{array} \mid$ & 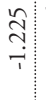 & $\begin{array}{l}0 \\
\text { Do } \\
\vdots \\
1\end{array}$ & 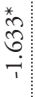 & $\begin{array}{l}0 \\
\infty \\
0 \\
i \\
i\end{array}$ & $\begin{array}{l}0 \\
\infty \\
0 \\
i \\
i\end{array}$ & \\
\hline & $\theta^{-1}$ & $\stackrel{N}{0}$ & $\begin{array}{l}\infty \\
\text { i } \\
i\end{array}$ & $\frac{1}{0}$ & 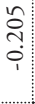 & iे & $\begin{array}{l}\infty \\
0 \\
0\end{array}$ & $\begin{array}{l}\infty \\
0 \\
0 \\
\vdots \\
1\end{array}$ & $\begin{array}{l}1 \\
0 \\
0 \\
1\end{array}$ & $\begin{array}{l}\tilde{D} \\
0 \\
0 \\
0\end{array}$ & $\begin{array}{l}\hat{N} \\
\vdots \\
0\end{array}$ & $\begin{array}{c}\overrightarrow{1} \\
0 \\
0 \\
1\end{array} \mid$ & $\overrightarrow{\widetilde{\sigma}}$ & $\begin{array}{l}\stackrel{\partial}{\partial} \\
\dot{\circ}\end{array}$ & $\mid \begin{array}{l}\vec{\infty} \\
0 \\
0\end{array}$ & $\begin{array}{l}\infty \\
\stackrel{0}{0} \\
\vdots\end{array}$ & $\begin{array}{l}1 \\
\delta \\
0\end{array}$ & $\begin{array}{l}a \\
0 \\
\vdots \\
1\end{array}$ & $\begin{array}{ll}0 \\
0 \\
\vdots \\
1\end{array}$ & $\begin{array}{l}\vec{\gamma} \\
\vdots \\
i\end{array}$ & $\begin{array}{l}v^{+1} \\
0 \\
\vdots \\
i\end{array}$ & $\begin{array}{l}\hat{n} \\
\dot{0} \\
i\end{array}$ & 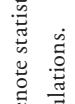 \\
\hline & $\mid$ & $\frac{\pi}{\circ}$ & $\begin{array}{l}\infty \\
0 \\
0 \\
0 \\
1 \\
1\end{array}$ & $\begin{array}{l}1 \\
\delta \\
0 \\
1 \\
1\end{array}$ & $\begin{array}{l}\text { Na } \\
\text { on } \\
\vdots \\
1\end{array}$ & $\begin{array}{l}0 \\
0 \\
0 \\
0 \\
1\end{array}$ & $\begin{array}{l}\infty \\
\vdots \\
0\end{array}$ & $\begin{array}{l}\text { ㅇl } \\
\text { o } \\
\vdots \\
\vdots\end{array}$ & $\begin{array}{l}\infty \\
0 \\
0 \\
0 \\
1\end{array}$ & $\begin{array}{l}\text { fै } \\
8 \\
\vdots \\
0\end{array}$ & 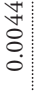 & $\begin{array}{c}\grave{D} \\
0 \\
\grave{1}\end{array}$ & $\begin{array}{l}+1 \\
\stackrel{2}{0} \\
\circ \\
\circ\end{array}$ & $\begin{array}{l}m \\
\text { an } \\
\vdots \\
\vdots\end{array}$ & $\begin{array}{l}\infty \\
0 \\
0 \\
0 \\
0\end{array}$ & $\begin{array}{ll}0 \\
\stackrel{1}{0}\end{array}$ & 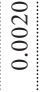 & $\begin{array}{l}0 \\
\tilde{o} \\
0 \\
0 \\
1\end{array}$ & $\begin{array}{l}0 \\
0 \\
0 \\
0 \\
1\end{array}$ & 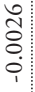 & 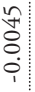 & $\begin{array}{c}\hat{\sigma} \\
\vdots \\
0 \\
0\end{array}$ & 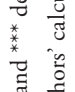 \\
\hline & & $\frac{0}{1}$ & $\uparrow$ & $\infty$ & গિ & י) & $\stackrel{\imath}{\imath}$ & +1 & $r$ & T & $T$ & 0 & $F$ & + & $\stackrel{m}{+}$ & + & $\stackrel{\sim}{+}$ & $\stackrel{0}{+}$ & †, & ${ }_{+\infty}^{\infty}$ & $q$ & $\frac{1}{+}$ & 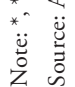 \\
\hline
\end{tabular}


Figure 1: CAARs for Agrokor Stocks for Observed Events, in the Event Windows

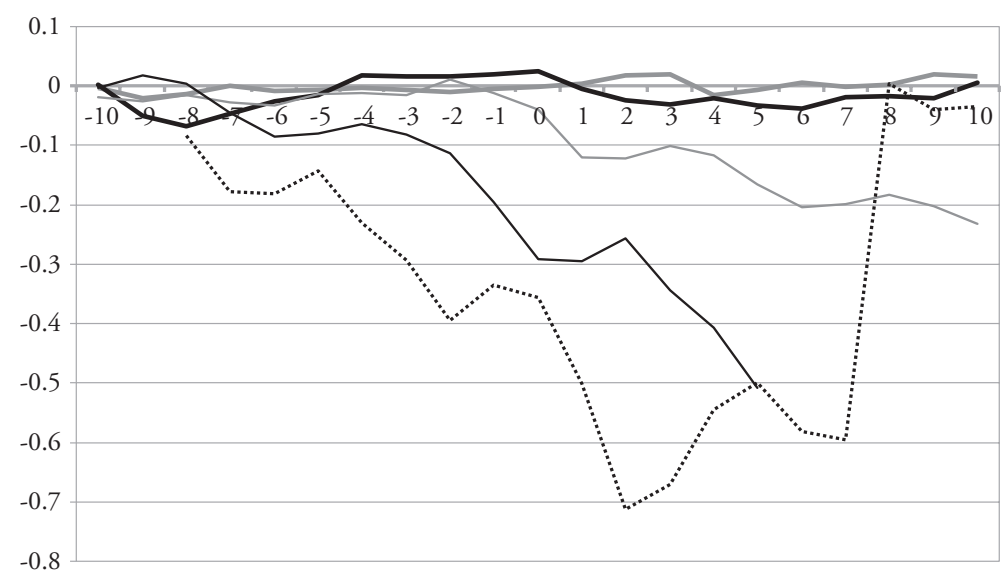

$$
\text { - Event } 1 \text { - Event } 2 \text { - Event } 3 \text { - Event } 4 \quad \text { … Event } 5
$$

Source: Authors' calculations.

Figure 2: CAARs for Other 24 Stocks for Observed Events, in the Event Windows

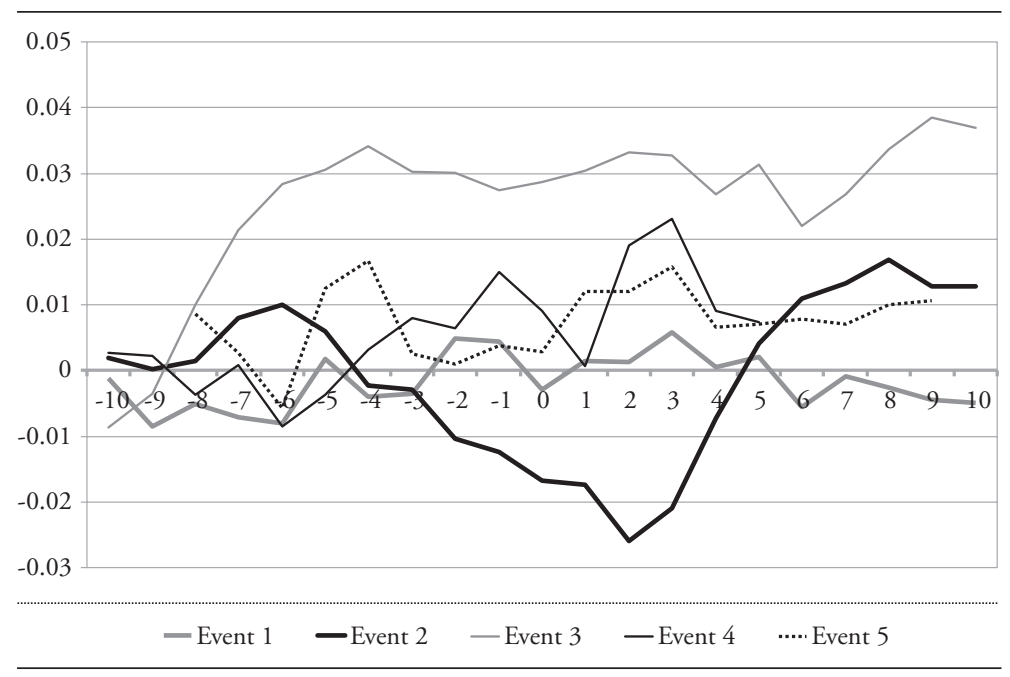

Source: Authors' calculations. 
The results are interesting in several ways, both for policymakers and investors. Firstly, big news (either positive or negative) and the nature of that news can have significant effects on stock prices. This was found to be true in this empirical study, as well as in the literature presented in the second section of the paper. Greater risks in economy and politics could lead potentially to lower returns, such as in Perotti and van Oijen (2001) or Lehkonen and Heimonen (2015). Policymakers should make prudent decisions, and not rash ones when interfering in the economy, especially when this concerns companies with stocks listed on capital markets. Investors speculating on the market could benefit from observing the chain of events which happened in the first quarter of 2017 and comparing the movements of stock prices in both groups examined in this study. When such information starts to get public, they could buy stocks from more stable companies and sell them to those getting rid of the losing stocks because this second group of investors (such as certain institutional investors) still need to have stocks in their portfolios due to legislative regulations.

\section{Conclusion}

This paper investigates how stock prices react to economic and political events using traditional event study methodology. It is tested on the Zagreb Stock Exchange for six stocks belonging to Agrokor and 24 other liquid and frequently traded stocks. Empirical evidence shows that there is a negative reaction of stock returns for the majority of the events regarding Agrokor stocks. The most significant events for Agrokor stocks in the tested period were on April 7 and April 10, when there was a significant return reaction during most of the event window period. When observing other stocks of companies that do not belong to Agrokor, we can see that the stock returns in the majority of cases did not react to political events connected with the problems in Agrokor. This conclusion is based upon non-significant results for almost every event. These conclusions are in line with other research in the field of banking and the "too big to fail" industries. The two major events which we could extract are the introduction 
of new legislation especially for the Agrokor case and the appointment of the new extraordinary commissioner for the concern. These events resulted in many controversies. Even while writing this research paper (May 2018), new news has been released regarding the new legislation and new insights have been gained into the problems regarding Agrokor. Some of them include Ivica Todorić submitting compromising documents to the court on certain top government officials and leakage of correspondence from 2017 between Martina Dalić (Deputy Prime Minister of Croatia) and financial and legal experts on Lex Agrokor.

Thus, we can conclude that the problems with Agrokor are far from over. One can expect that political events regarding this concern will surely affect stock prices in Croatia in the future as well. Based upon the results in this study, we can expect that negative news will contribute to even lower stock prices and negative returns of stocks belonging to the Agrokor concern. However, it is questionable how it will affect other stocks and their returns. If investors lose faith in Croatia's other industry sectors, they could move their investments into other countries as well.

Some of the contributions of this research come from observing the effects of recent and still ongoing political events on the Croatian stock market, which has not been conducted yet as in this study. Namely, the effects were divided into two distinctive groups of stocks in order to simultaneously observe the results. The main shortcoming of this research was the small number of stocks in the analysis, in both groups. This is especially true for the number of Agrokor stocks. However, included stocks were the only ones traded on the ZSE. Future research should include newer, currently ongoing political events regarding Agrokor in order to observe the intensity of these newer events on stock returns. Other events could be included as well in order to observe how they affect the market as a whole. Moreover, the research could be extended to trading volume and stock return volatility. In that way, investors and other interested parties can get more information on the effects of political (and other) events on the Croatian stock market. 


\section{Appendix}

Table A1: List of Stocks in the Study

\begin{tabular}{c|c|c|c}
\hline Stock & \% of non-trading days & Stock & \% of non-trading days \\
\hline ADPL & 10 & LEDO & 23 \\
\hline ADRS & 8 & LKPC & 20 \\
\hline ARNT & 15 & LKRI & 28 \\
\hline ATGR & 8 & MAIS & 29 \\
\hline ATPL & 9 & OPTE & 21 \\
\hline BELJE & 10 & PODR & 7 \\
\hline DDJH & 4 & PTKM & 27 \\
\hline DLKV & 5 & RIVP & 5 \\
\hline ERNT & 7 & RIZO & 31 \\
\hline HT & 4 & TISK & 77 \\
\hline IGH & 35 & ULPL & 19 \\
\hline INGR & 17 & VART & 29 \\
\hline JMNC & 64 & VPIK & 24 \\
\hline KOEI & 21 & ZABA & 17 \\
\hline KRAS & 39 & ZVZD & 44 \\
\hline
\end{tabular}

Source: Zagreb Stock Exchange (2018). 
Table A2: Estimation Results of Model (4) for 24 Stocks

\begin{tabular}{|c|c|c|c|c|c|}
\hline Stock & $\alpha$ & $p$-value $(\alpha)$ & $\beta$ & $p$-value $(\beta)$ & $R^{2}$ \\
\hline ADPL & 0.001056 & 0.2048 & 0.407066 & 0.0657 & 0.012121 \\
\hline ADRS & 0.000143 & 0.8276 & 1.20849 & 0.0000 & 0.250907 \\
\hline ARNT & 0.000570 & 0.4988 & 0.493171 & 0.0113 & 0.020188 \\
\hline ATGR & -0.000101 & 0.7121 & 0.435484 & 0.0000 & 0.127492 \\
\hline ATPL & 0.001058 & 0.6711 & 2.394133 & 0.0000 & 0.096020 \\
\hline DDJH & 0.001459 & 0.4579 & 1.087325 & 0.0348 & 0.025182 \\
\hline DLKV & -0.000184 & 0.8880 & 0.451096 & 0.1515 & 0.008028 \\
\hline ERNT & -0.000180 & 0.7973 & 0.880088 & 0.0000 & 0.103108 \\
\hline $\mathrm{HT}$ & 0.000272 & 0.5514 & 0.717938 & 0.0000 & 0.183860 \\
\hline $\mathrm{IGH}$ & 0.002299 & 0.4809 & 0.291469 & 0.6931 & 0.000599 \\
\hline INGR & -0.000087 & 0.9535 & 0.050028 & 0.9094 & 0.000050 \\
\hline KOEI & -0.000685 & 0.1915 & 1.218349 & 0.0000 & 0.201153 \\
\hline KRAS & 0.000227 & 0.6788 & 0.214926 & 0.0766 & 0.009879 \\
\hline LKPC & -0.001181 & 0.0921 & 0.468258 & 0.0634 & 0.022636 \\
\hline LKRI & -0.000422 & 0.5989 & 0.824608 & 0.0003 & 0.035570 \\
\hline MAIS & -0.000269 & 0.7435 & 0.827402 & 0.0037 & 0.040585 \\
\hline OPTE & 0.000670 & 0.6938 & 0.994534 & 0.0804 & 0.020268 \\
\hline PODR & -0.000348 & 0.4724 & 1.303312 & 0.0000 & 0.283133 \\
\hline PTKM & 0.000714 & 0.7586 & 0.770106 & 0.1679 & 0.007796 \\
\hline RIVP & 0.000634 & 0.2988 & 1.204529 & 0.0000 & 0.263982 \\
\hline RIZO & -0.002603 & 0.1552 & 2.055367 & 0.0062 & 0.063405 \\
\hline ULPL & -0.000466 & 0.7849 & 1.201290 & 0.0039 & 0.038349 \\
\hline VART & -0.000338 & 0.8380 & 0.415308 & 0.3083 & 0.003378 \\
\hline $\mathrm{ZABA}$ & 0.000360 & 0.6577 & 1.561761 & 0.0000 & 0.154721 \\
\hline
\end{tabular}

Note: $p$-values were calculated based upon Newey-West (1987) corrections of standard errors.

Source: Authors' calculations.

Table A3: Estimation Results of Model (4) for Six Agrokor Stocks

\begin{tabular}{c|c|c|c|c|c}
\hline Stock & $\alpha$ & $p$-value $(\alpha)$ & $\beta$ & $p$-value $(\beta)$ & $R^{2}$ \\
\hline BELJE & -0.000713 & 0.5626 & 0.846193 & 0.0239 & 0.026985 \\
JMNC & 0.000603 & 0.4622 & 0.348358 & 0.1001 & 0.014236 \\
LEDO & 0.005159 & 0.8749 & -7.512723 & 0.5776 & 0.001302 \\
\hline TISK & -0.000450 & 0.7247 & -0.062810 & 0.7126 & 0.000235 \\
VPIK & -0.001713 & 0.4100 & 1.932372 & 0.0003 & 0.050334 \\
ZVDZ & 0.002166 & 0.1336 & 0.372999 & 0.2068 & 0.005720 \\
\hline
\end{tabular}

Note: $p$-values were calculated based upon Newey-West (1987) corrections of standard errors.

Source: Authors' calculations. 
Table A4: Sign Tests for Other 24 Stocks for Event 1

\begin{tabular}{|c|c|c|c|}
\hline \multirow[b]{2}{*}{ Day $\tau$ / test } & \multicolumn{3}{|c|}{ Event 1 test values } \\
\hline & Sign (exact binomial) & $\begin{array}{c}\text { Sign (normal } \\
\text { approximation) }\end{array}$ & Wilcoxon signed rank \\
\hline-10 & $17^{*}$ & $1.837117^{*}$ & 1.500000 \\
\hline-9 & 14 & 0.612372 & 1.242857 \\
\hline-8 & 15 & 1.020621 & 1.214286 \\
\hline-7 & 13 & 0.204124 & 0.785714 \\
\hline-6 & 14 & 0.612372 & 1.128571 \\
\hline-5 & 14 & 0.612372 & 0.328571 \\
\hline-4 & 13 & 0.204124 & 0.871429 \\
\hline-3 & 13 & 0.204124 & 0.471429 \\
\hline-2 & 14 & 0.612372 & 0.814286 \\
\hline-1 & 13 & 0.204124 & 0.614286 \\
\hline 0 & 14 & 0.612372 & 0.557143 \\
\hline+1 & 12 & -0.204124 & 0.128571 \\
\hline+2 & 13 & 0.204124 & 0.014286 \\
\hline+3 & 13 & 0.204124 & 0.385714 \\
\hline+4 & 13 & 0.204124 & 0.128571 \\
\hline+5 & 14 & 0.612372 & 0.128571 \\
\hline+6 & 15 & 1.020621 & 0.700000 \\
\hline+7 & 14 & 0.612372 & 0.300000 \\
\hline+8 & 16 & 1.428869 & 0.700000 \\
\hline+9 & 14 & 0.612372 & 0.842857 \\
\hline+10 & 14 & 0.612372 & 0.842857 \\
\hline
\end{tabular}

Note ${ }^{*}, * *$, and ${ }^{* * *}$ denote statistical significance at 10,5 , and 1 percent.

Source: Authors' calculations. 
Table A5: Sign Tests for Other 24 Stocks for Event 2

\begin{tabular}{|c|c|c|c|}
\hline \multirow[b]{2}{*}{ Day $\tau$ / test } & \multicolumn{3}{|c|}{ Event 2 test values } \\
\hline & Sign (exact binomial) & $\begin{array}{c}\text { Sign (normal } \\
\text { approximation) }\end{array}$ & Wilcoxon signed rank \\
\hline-10 & 13 & 0.204124 & 0.414286 \\
\hline-9 & 14 & 0.612372 & 1.614286 \\
\hline-8 & 12 & -0.204124 & 0.871429 \\
\hline-7 & 13 & 0.204124 & 0.214286 \\
\hline-6 & 13 & 0.204124 & 0.557143 \\
\hline-5 & 12 & -0.204124 & 0.271429 \\
\hline-4 & 13 & 0.204124 & 0.014286 \\
\hline-3 & 13 & 0.204124 & 0.214286 \\
\hline-2 & 14 & 0.612372 & 0.957143 \\
\hline-1 & 13 & 0.204124 & 0.528571 \\
\hline 0 & 14 & 0.612372 & 0.642857 \\
\hline+1 & 14 & 0.612372 & 0.871429 \\
\hline+2 & 12 & -0.204124 & 0.585714 \\
\hline+3 & 12 & -0.204124 & 0.157143 \\
\hline+4 & 13 & 0.204124 & 0.471429 \\
\hline+5 & 13 & 0.204124 & 0.385714 \\
\hline+6 & 13 & 0.204124 & 0.757143 \\
\hline+7 & 14 & 0.612327 & 0.900000 \\
\hline+8 & 15 & 1.020621 & 1.214286 \\
\hline+9 & 14 & 0.612327 & 1.242857 \\
\hline+10 & 15 & 1.020621 & 1.185714 \\
\hline
\end{tabular}

Note ${ }^{*}, * *$, and ${ }^{* * *}$ denote statistical significance at 10,5 , and 1 percent.

Source: Authors' calculations. 
Table A6: Sign Tests for Other 24 Stocks for Event 3

\begin{tabular}{|c|c|c|c|}
\hline \multirow[b]{2}{*}{ Day $\tau$ / test } & \multicolumn{3}{|c|}{ Event 3 test values } \\
\hline & Sign (exact binomial) & $\begin{array}{c}\text { Sign (normal } \\
\text { approximation) }\end{array}$ & Wilcoxon signed rank \\
\hline-10 & 13 & 0.204124 & 1.414286 \\
\hline-9 & 14 & 0.612372 & 0.414286 \\
\hline-8 & 14 & 0.612372 & 1.157143 \\
\hline-7 & 14 & 0.612372 & 1.614286 \\
\hline-6 & 14 & 0.612372 & 1.528571 \\
\hline-5 & 12 & -0.204124 & 0.985714 \\
\hline-4 & 12 & -0.204124 & 1.328571 \\
\hline-3 & 12 & -0.204124 & 1.071429 \\
\hline-2 & 13 & 0.204124 & 1.242857 \\
\hline-1 & 12 & -0.204124 & 0.814286 \\
\hline 0 & 14 & 0.612327 & 1.014286 \\
\hline+1 & 13 & 0.204124 & 1.500000 \\
\hline+2 & 13 & 0.204124 & 1.442857 \\
\hline+3 & 13 & 0.204124 & 1.214286 \\
\hline+4 & 13 & 0.204124 & 1.042857 \\
\hline+5 & 14 & 0.612372 & 1.328571 \\
\hline+6 & I & 1 & I \\
\hline+7 & I & 1 & l \\
\hline+8 & I & I & I \\
\hline+9 & I & 1 & I \\
\hline+10 & 1 & 1 & 1 \\
\hline
\end{tabular}

Note ${ }^{*}, * *$, and ${ }^{* * *}$ denote statistical significance at 10,5 , and 1 percent.

Source: Authors' calculations. 
Table A7: Sign Tests for Other 24 Stocks for Events 4 and 5

\begin{tabular}{|c|c|c|c|}
\hline \multirow[b]{2}{*}{ Day $\tau$ / test } & \multicolumn{3}{|c|}{ Event 4 and 5 test values } \\
\hline & Sign (exact binomial) & $\begin{array}{c}\text { Sign (normal } \\
\text { approximation) }\end{array}$ & Wilcoxon signed rank \\
\hline-7 & 16 & 1.428869 & 1.242857 \\
\hline-6 & 15 & 1.020621 & 0.442857 \\
\hline-5 & 14 & 0.612372 & 0.328571 \\
\hline-4 & $18^{* *}$ & $2.245366^{* *}$ & 1.528571 \\
\hline-3 & $17^{*}$ & $1.837117^{*}$ & 1.242857 \\
\hline-2 & 15 & 1.020621 & 0.928571 \\
\hline-1 & 15 & 1.020621 & 0.757143 \\
\hline 0 & 15 & 1.020621 & 0.842857 \\
\hline 0 & 15 & 1.020621 & 0.728571 \\
\hline+1 & 15 & 1.020621 & 1.014286 \\
\hline+2 & 16 & 1.428869 & 0.757143 \\
\hline+3 & $17^{*}$ & $1.837117^{*}$ & 1.442857 \\
\hline+4 & $17^{*}$ & $1.837117^{*}$ & 1.100000 \\
\hline+5 & 14 & 0.612327 & 0.785714 \\
\hline+6 & $17^{*}$ & $1.837117^{*}$ & 0.928571 \\
\hline+7 & $17^{*}$ & $1.837117^{*}$ & 0.814286 \\
\hline+8 & 16 & 1.428869 & 0.671429 \\
\hline+9 & 16 & 1.428869 & 1.014286 \\
\hline+10 & 16 & 1.428869 & 1.185714 \\
\hline
\end{tabular}

Note ${ }^{*}, * *$ and ${ }^{* * *}$ denote statistical significance at 10,5 , and 1 percent.

Source: Authors' calculations. 
Table A8: Sign Tests for Agrokor Stocks for Event 1

\begin{tabular}{|c|c|c|c|}
\hline \multirow[b]{2}{*}{ Day $\tau$ / test } & \multicolumn{3}{|c|}{ Event 1 test values } \\
\hline & Sign (exact binomial) & $\begin{array}{c}\text { Sign (normal } \\
\text { approximation) }\end{array}$ & Wilcoxon signed rank \\
\hline-10 & 4 & 0.408248 & 0.838628 \\
\hline-9 & 5 & 1.224745 & $1.886913^{*}$ \\
\hline-8 & 4 & 0.408248 & 1.048285 \\
\hline-7 & 4 & 0.408248 & 0.209657 \\
\hline-6 & 4 & 0.408248 & 0.628971 \\
\hline-5 & 5 & 1.224745 & 0.838628 \\
\hline-4 & 5 & 1.224745 & 0.838628 \\
\hline-3 & 5 & 1.224745 & 0.838628 \\
\hline-2 & 4 & 0.408248 & 0.628971 \\
\hline-1 & 4 & 0.408248 & 0.419314 \\
\hline 0 & 4 & 0.408248 & 0.000000 \\
\hline+1 & 5 & 1.224745 & 0.838628 \\
\hline+2 & 3 & -0.408248 & 0.209657 \\
\hline+3 & 3 & -0.408248 & 0.209657 \\
\hline+4 & 5 & 1.224745 & 0.838628 \\
\hline+5 & 4 & 0.408248 & 0.628971 \\
\hline+6 & 4 & 0.408248 & 0.628971 \\
\hline+7 & 4 & 0.408248 & 0.628971 \\
\hline+8 & 3 & -0.408248 & 0.209657 \\
\hline+9 & 3 & -0.408248 & 0.209657 \\
\hline+10 & 3 & -0.408248 & 0.209657 \\
\hline
\end{tabular}

Note ${ }^{*}, * *$, and ${ }^{* * *}$ denote statistical significance at 10,5 , and 1 percent.

Source: Authors' calculations. 
Table A9: Sign Tests for Agrokor Stocks for Event 2

\begin{tabular}{|c|c|c|c|}
\hline \multirow[b]{2}{*}{ Day $\tau$ / test } & \multicolumn{3}{|c|}{ Event 2 test values } \\
\hline & Sign (exact binomial) & $\begin{array}{c}\text { Sign (normal } \\
\text { approximation) }\end{array}$ & Wilcoxon signed rank \\
\hline-10 & 5 & 1.224745 & 0.838628 \\
\hline-9 & 4 & 0.408248 & 1.257942 \\
\hline-8 & $6^{* *}$ & $2.041241^{* *}$ & $2.096570^{* *}$ \\
\hline-7 & 5 & 1.224745 & $1.677256^{*}$ \\
\hline-6 & 4 & 0.408248 & 1.467599 \\
\hline-5 & 3 & -0.408248 & 0.838628 \\
\hline-4 & 3 & -0.408248 & 0.209657 \\
\hline-3 & 4 & 0.408248 & 0.000000 \\
\hline-2 & 4 & 0.408248 & 0.000000 \\
\hline-1 & 4 & 0.408248 & 0.000000 \\
\hline 0 & 3 & -0.408248 & 0.209657 \\
\hline+1 & 4 & 0.408248 & 0.000000 \\
\hline+2 & 4 & 0.408248 & 0.419314 \\
\hline+3 & 5 & 1.224745 & 0.838628 \\
\hline+4 & 4 & 0.408248 & 0.628971 \\
\hline+5 & 4 & 0.408248 & 0.838628 \\
\hline+6 & 5 & 1.224745 & 1.048285 \\
\hline+7 & 4 & 0.408248 & 0.628971 \\
\hline+8 & 3 & -0.408248 & 0.209657 \\
\hline+9 & 4 & 0.408248 & 0.419314 \\
\hline+10 & 4 & 0.408248 & 0.209657 \\
\hline
\end{tabular}

Note ${ }^{*},{ }^{* *}$, and ${ }^{* * *}$ denote statistical significance at 10,5 , and 1 percent.

Source: Authors' calculations. 
Table A10: Sign Tests for Agrokor Stocks for Event 3

\begin{tabular}{|c|c|c|c|}
\hline \multirow[b]{2}{*}{ Day $\tau$ / test } & \multicolumn{3}{|c|}{ Event 3 test values } \\
\hline & Sign (exact binomial) & $\begin{array}{c}\text { Sign (normal } \\
\text { approximation) }\end{array}$ & Wilcoxon signed rank \\
\hline-10 & 5 & 1.224745 & $1.677256^{*}$ \\
\hline-9 & 4 & 0.408248 & 1.257942 \\
\hline-8 & 5 & 1.224745 & 1.048285 \\
\hline-7 & 5 & 1.224745 & 1.257942 \\
\hline-6 & 5 & 1.224745 & 1.257942 \\
\hline-5 & 4 & 0.408248 & 0.628971 \\
\hline-4 & 5 & 1.224745 & 0.838628 \\
\hline-3 & 5 & 1.224745 & 1.048285 \\
\hline-2 & 4 & 0.408248 & 0.000000 \\
\hline-1 & 4 & 0.408248 & 0.628971 \\
\hline 0 & 4 & 0.408248 & 1.048285 \\
\hline+1 & 3 & -0.408248 & 0.838628 \\
\hline+2 & 4 & 0.408248 & 1.048285 \\
\hline+3 & 3 & -0.408248 & 0.838628 \\
\hline+4 & 3 & -0.408248 & 0.838628 \\
\hline+5 & 4 & 0.408248 & 1.048285 \\
\hline+6 & 3 & -0.408248 & 0.838628 \\
\hline+7 & 3 & -0.408248 & 0.838628 \\
\hline+8 & 5 & 1.224745 & 1.467599 \\
\hline+9 & 5 & 1.224745 & 1.467599 \\
\hline+10 & 4 & 0.408248 & 1.048285 \\
\hline
\end{tabular}

Note ${ }^{*}, * *$, and ${ }^{* * *}$ denote statistical significance at 10,5 , and 1 percent.

Source: Authors' calculations. 
Table A11: Sign Tests for Agrokor Stocks for Events 4 and 5

\begin{tabular}{|c|c|c|c|}
\hline \multirow[b]{2}{*}{ Day $\tau$ / test } & \multicolumn{3}{|c|}{ Event 4 and 5 test values } \\
\hline & Sign (exact binomial) & $\begin{array}{c}\text { Sign (normal } \\
\text { approximation) }\end{array}$ & Wilcoxon signed rank \\
\hline-7 & 4 & 0.408248 & 0.838628 \\
\hline-6 & 5 & 1.224745 & 1.467599 \\
\hline-5 & 5 & 1.224745 & $1.677256^{*}$ \\
\hline-4 & 5 & 1.224745 & $1.886913^{*}$ \\
\hline-3 & $6^{* *}$ & $2.041241^{* *}$ & $2.096570^{* *}$ \\
\hline-2 & 5 & 1.224745 & $1.886913^{*}$ \\
\hline-1 & 5 & 1.224745 & $1.886913^{*}$ \\
\hline 0 & 5 & 1.224745 & $1.677256^{*}$ \\
\hline 0 & 4 & 0.408248 & 1.467599 \\
\hline+1 & 5 & 1.224745 & $1.886913^{*}$ \\
\hline+2 & $6^{* *}$ & $2.041241^{* *}$ & $2.096570^{* *}$ \\
\hline+3 & $6^{* *}$ & $2.041241^{* *}$ & $2.096570^{* *}$ \\
\hline+4 & $6^{* *}$ & $2.041241^{* *}$ & $2.096570^{* *}$ \\
\hline+5 & $6^{* *}$ & $2.041241^{* *}$ & $2.096570^{* *}$ \\
\hline+6 & $6^{* *}$ & $2.041241^{* *}$ & $2.096570^{* *}$ \\
\hline+7 & $6^{* *}$ & $2.041241^{* *}$ & $2.096570^{* *}$ \\
\hline+8 & $6^{* *}$ & $2.041241^{* *}$ & $2.096570^{* *}$ \\
\hline+9 & $6^{* *}$ & $2.041241^{* *}$ & $2.096570^{* *}$ \\
\hline+10 & $6^{* *}$ & $2.041241^{* *}$ & $2.096570^{* *}$ \\
\hline
\end{tabular}

Note ${ }^{*}, * *$, and ${ }^{* * *}$ denote statistical significance at 10,5 , and 1 percent.

Source: Authors' calculations. 
Figure A1-A5: CAARs for Individual Events, Agrokor Stocks

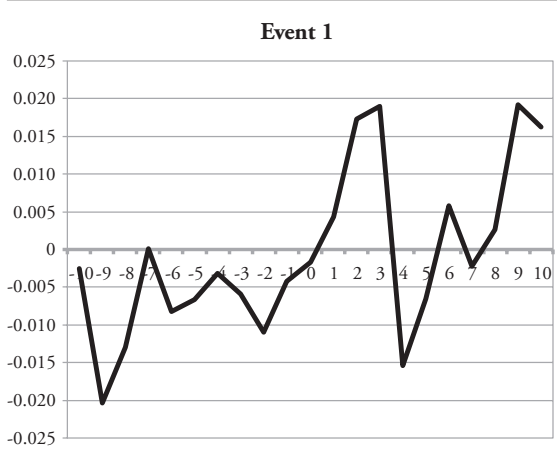

Event 3

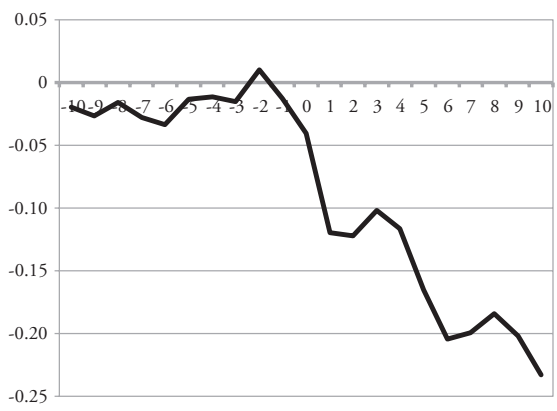

Event 2

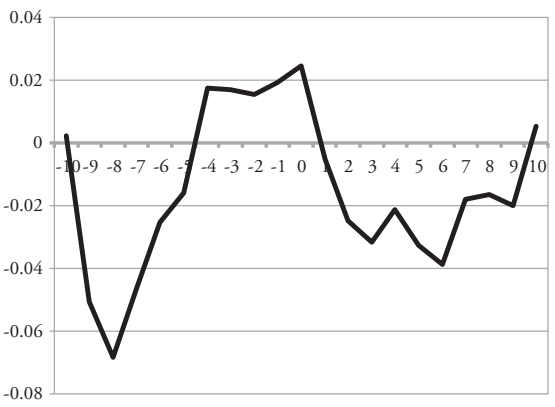

Event 4

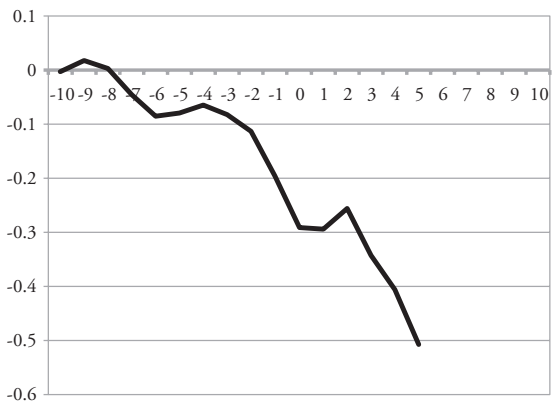

Event 5

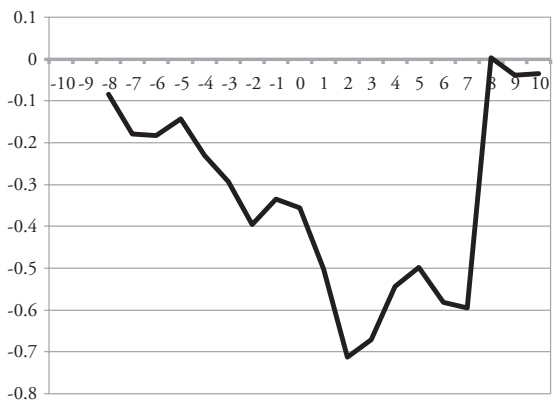

Source: Authors' calculations. 


\section{Literature}

Agrokor. (2017). Financial report. Retrieved from: http://www.agrokor.hr/en/ news/presentation-of-audited-financial-statements-for-2016/.

Angelovska, J. (2017). Investors' behaviour in regard to company earnings announcements during the recession period: Evidence from the Macedonian stock exchange. Economic Research-Ekonomska istraživanja, 30(1), 647-660. doi: https://doi.org/10.1080/1331677X.2017.1305768

Asteriou, D., \& Sarantidis, A. (2016). Political instability and stock market returns: Evidence from OECD countries. Economics and Business Letters, 5(4), 113-124. doi: https://doi.org/10.17811/ebl.5.4.2016.113-124

Barbić, T., \& Čondić-Jurkić, I. (2017). Do fiscal variables affect stock market returns in EU countries? Ekonomski pregled, 68(3), 253-266. Retrieved from: https://hrcak.srce.hr/file/272191.

Bartholdy, J., Olson, D., \& Peare, P. (2007). Conducting event studies on a small stock exchange. The European Journal of Finance, 13(3), 227-252. doi: https:// doi.org/10.1080/13518470600880176

Benazić, M. (2008). Povezanost cijene dionica i deviznog tečaja u Republici Hrvatskoj. Ekonomski pregled, 59(1), 669-687. Retrieved from: https://hrcak. srce.hr/file/53090.

Białkowski, J., Gottschalk, K., \& Wisniewski, T. (2008). Stock market volatility around national elections. Journal of Banking \& Finance, 32(9), 1941-1953. doi: https://doi.org/10.1016/j.jbankfin.2007.12.021

Bongini, P., Nieri, L., \& Pelagatti, M. (2015). The importance of being systematically important financial institutions. Journal of Banking \& Finance, 50, 562-574. doi: https://doi.org/10.1016/j.jbankfin.2014.07.006

Burdekin, R. C. K., Hugson, E. N., \& Gu, J. (2017). A first look at Brexit and global equity markets. Applied Economics Letters, 25(2), 136-140. doi: https:// doi.org/10.1080/13504851.2017.1302057 
Capstaff, J., Klaeboe, A., \& Marshall, A. P. (2004). Share price reaction to dividend announcements: Empirical evidence on the signaling model from the Oslo Stock Exchange. Multinational Finance Journal, 8(1-2), 115-139. doi: https://doi.org/10.17578/8-1/2-4

Cetorelli, N., \& Traina, J. (2018). Resolving "too big to fail". Federal Reserve Bank of New York Staff Report No. 859. doi: https://doi.org/10.2139/ssrn.3200044

Chang, T., Chen, W.-Y., Gupta, R., \& Nguyen, D. K. (2015). Are stock prices related to the political uncertainty index in OECD countries? Evidence from the bootstrap panel causality test. Economic Systems, 39(2), 288-300. doi: https://doi. org/10.1016/j.ecosys.2014.10.005

Chaudary, S., \& Mirza, N. (2017). Domestic and cross-border returns to bidders in acquisitions into the EU. Economic Research-Ekonomska istraživanja, 30(1), 1021-1032. doi: https://doi.org/10.1080/1331677X.2017.1311228

Cochrane, J. (2008). The dog that did not bark: A defense of return predictability. The Review of Financial Studies, 21(4), 1533-1575. doi: https:/doi.org/10.1093/ rfs/hhm046

Cooper, M., Gulen, H., \& Ovtchinnikov, A. (2010). Corporate political contributions and stock returns. Journal of Finance, 65(2), 687-724. doi: https:// doi.org/10.1111/j.1540-6261.2009.01548.x

Croatian National Bank. (2017). Macroeconomic developments and outlook, Vol. 2, No. 2. Retrieved from: http://www.hnb.hr.

Dangol, J. (2008). Unanticipated political events and stock returns: An event study. NRB Economic Review, 20, 86-110. Retrieved from: https://ideas.repec. org/a/nrb/journl/v20y2008p86-110.html.

Diamonte, R., Liew, J., \& Stevens, R. (1996). Political risk in emerging and developed markets. Financial Analysts Journal, 52(3), 71-76. doi: https://doi. org/10.2469/faj.v52.n3.1998 
Erb, C. B., Harvey, C. R., \& Viskanta, T. E., (1996). Political risk, economic risk, and financial risk. Financial Analysts Journal, 52(6), 29-46. doi: https://doi. org/10.2469/faj.v52.n6.2038

Fama, E. F. (1965). The behavior of stock market prices. Journal of Business, 38(1), 34-105. doi: https://doi.org/10.1086/294743

Fama, E. F. (1970). Efficient capital markets: A review of theory and empirical work. Journal of Finance, 25(2), 383-417. doi: https://doi.org/10.2307/2325486

Gopalaswamy, A. K., Acharya, D., \& Malik, J. (2008). Stock price reaction to merger announcements: An empirical note on Indian markets. Investment Management and Financial Innovations, 5(1), 95-103. Retrieved from: https:// businessperspectives.org/images/pdf/applications/publishing/templates/article/ assets/2081/imfi_en_2008_01_Gopalaswamy.pdf.

Gregoriou, A. (2011). The liquidity effects of revisions to the CAC40 stock index. Applied Financial Economics, 21(5), 333-341. doi: https://doi.org/10.1080/096 03107.2010.530216

Hanfa. (2017). Annual report. Retrieved from: https:/www.hanfa.hr/publications/ annual-report/.

Harvey, C., Liu, Y., \& Zhu, H. (2014). ... and the cross-section of expected returns. Duke University Working Paper. Retrieved from: http://finpko.faculty. ku.edu/myssi/FIN938/Harvey\%20Liu\%20\%26\%20Zhu_...\%20\%26\%20 Cross-Section\%20of\%20Expected\%20Returns_WP_2014.pdf.

Hendricks, K., \& Singhal, V. (2005). An empirical analysis of the effect of supply chain disruptions on long-run stock price performance and equity risk of the firm. Production and Operations Management, 14(1), 35-52. doi: https://doi. org/10.1111/j.1937-5956.2005.tb00008.x

Heston, S. L., \& Sinha, N. R. (2016). News versus sentiment: Predicting stock returns from news stories. Federal Reserve System, Finance and Economics Discussion Series 2016-048. doi: https://doi.org/10.17016/feds.2016.048 
Hsing, Y. (2011). Macroeconomic variables and the stock market: The case of Croatia. Economic Research-Ekonomska istraživanja, 24(4), 41-50. doi: https:// doi.org/10.1080/1331677X.2011.11517479

Irshad, H. (2017). Relationship among political instability, stock market returns and stock market volatility. Studies in Business and Economics, 12(2), 70-99. doi: https://doi.org/10.1515/sbe-2017-0023

Ivanković, Ž. (2017). The political economy of crony capitalism: A case study of the collapse of the largest Croatian conglomerate. Politicka misao, 54(4), 40-60. Retrieved from: https://hrcak.srce.hr/190337.

Ivanov, M., \& Lovrinović, I. (2008). Monetary transmission mechanism and behaviour of asset prices: The case of Croatia. Review of Business Research, 8(2), 1-17. Retrieved from: http://rbr-journal.org/domains/RBR-JOURNAL/ Documents/Abstracts/RBR-8-2_Abstracts.pdf.

Klepo, M., Bićanić, I., \& Ivanković, Ž. (2017). The case of Agrokor: The crisis of the largest Croatian company. Friedrich Ebert Stiftung Analysis. Retrieved from: http://www.fes-croatia.org/fileadmin/user_upload/171109_Agrokor_WEB.pdf.

Kothari, S. P., \& Warner, J. B. (2007). Econometrics of event studies. In B. E. Eckbo (Ed.), Handbook of corporate finance: Empirical corporate finance (Vol. 1, pp. 3-36). Amsterdam: Elsevier.

Koulakiotis, A., Papapanagos, H., \& Papasyriopolos, N. (2016). Political elections, abnormal returns and stock price volatility: The case of Greece. Investment Management and Financial Innovations, 13(1), 161-169. doi: https:// doi.org/10.21511/imfi.13(1-1).2016.03

Lehkonen, H., \& Heimonen, K. (2015). Democracy, political risks and stock market performance. Journal of International Money and Finance, 59, 77-99. doi: https://doi.org/10.1016/j.jimonfin.2015.06.002

MacKinlay, C. (1997). Event studies in economics and finance. Journal of Economic Literature, 35, 13-39. Retrieved from: https://pdfs.semanticscholar. org/aac6/83a678a12a3dcd73389aac7289868847ea73.pdf. 
Mahmood, S., Irfan, M., Iqbal, S., Kamran, M., \& Ijaz, A. (2014). Impact of political events on stock market: Evidence from Pakistan. Journal of Asian Business Strategy, 4(12), 163-174. Retrieved from: http://www.aessweb.com/pdf-files/1156-4(12)2014-JABS-163-174.pdf.

Miletić, M. (2011). Stock price reaction to dividend announcement in Croatia. Economic research-Ekonomska istraživanja, 24(3), 147-156. doi: https://doi.org/1 0.1080/1331677X.2011.11517473

Mlonzi, V. F., Kruger, J., \& Nthoesane, M. G. (2011). Share price reaction to earnings announcement on the JSE-ALtX: A test for market efficiency. Southern African Business Review, 15(3), 142-166. Retrieved from: https://www.ajol.info/ index.php/sabr/article/viewFile/76409/66867.

Moody's. (2018a). Moody's downgrades Agrokor to B3; outlook stable. Retrieved from: https://www.moodys.com/research/Moodys-downgrades-Agrokor-to-B3outlook-stable--PR_360263.

Moody's. (2018b). Moody's downgrades Agrokor to Caal; outlook negative. Retrieved from: https://www.moodys.com/research/Moodys-downgrades-Agrokor-toCaa1-outlook-negative--PR_364254.

Mrzygłód, U., \& Nowak, S. (2017). Market reactions to dividends announcements and payouts: Empirical evidence from the Warsaw Stock Exchange. Contemporary Economics, 11(2), 187-204. doi: https://doi.org/10.5709/ce.1897-9254.236

Nageswara, R., \& Sreejith, U. (2014). Event study methodology: A critical review. The Macrotheme Review, 3(1), 40-53. Retrieved from: http://macrotheme.com/ yahoo_site_admin/assets/docs/3MR31ASr.1334942.pdf.

Newey, W., \& West, K. D. (1987). A simple, positive semi-definite, heteroskedasticity and autocorrelation consistent covariance matrix. Econometrica, 55(3), 703-708. doi: https://doi.org/10.2307/1913610

Obradović, S., \& Tomić, N. (2017). The effect of presidential election in the USA on stock return flow: A study of a political event. Economic ResearchEkonomska istraživanja, 30(1), 112-124. doi: https://doi.org/10.1080/133167 7X.2017.1305802 
Perotti, E., \& van Oijen, P. (2001). Privatization, political risk and stock market development in emerging markets. Journal of International Money and Finance, 20(1), 43-69. doi: https://doi.org/10.1016/S0261-5606(00)00032-2

Rančić, N. (2018). Agrokor - A case of controlled collapse. Economic and Social Development, Book of Proceedings, 27th International Scientific Conference on Economic and Social Development, 753-762. Retrieved from: https://bib.irb.hr/ datoteka/931245.8._Zbornik_radova_konferencija_Rim.pdf\#page=764.

Rubinić, I., \& Bodul, D. (2018). Regulation of the too-big-to-fail entities in the Republic of Croatia. Ekonomski pregled, 69(3), 298-321. Retrieved from: https:// hrcak.srce.hr/202520.

Schwert, W. (1990). Stock returns and real activity: A century of evidence. Journal of Finance, 45(4), 1237-1257. doi: https://doi.org/10.1111/j.1540-6261.1990. tb02434.x

Shaheen, I. (2006). Stock market reaction to acquisition announcements using an event study approach (Doctoral dissertation). Franklin and Marshall College, Lancaster, PA.

Sheskin, D. J. (1997). Handbook of parametric and nonparametric statistical procedures (First edition). Boca Raton, FL: CRC Press.

Sheskin, D. J. (2004). Handbook of parametric and nonparametric statistical procedures (Fourth edition). Boca Raton, FL: CRC Press.

Stern, G., \& Feldman, R. (2004). Too big to fail: The hazards of bank bailouts. Washington, DC: Brookings Institution Press.

von Gersdorff, N., \& Bacon, F. (2009). US mergers and acquisitions: A test of market efficiency. Journal of Finance and Accountancy, 1(1), 1-8. Retrieved from: http://citeseerx.ist.psu.edu/viewdoc/summary?doi=10.1.1.493.3750.

Zagreb Stock Exchange. (2018). Trading data and statistics. Retrieved from: http://zse.hr/default.aspx?id=26495.

Zanghieri, P. (2017). The value and price of a "too-big-to-fail" guarantee: Evidence from the insurance industry. Journal of Financial Perspectives, 4(1), 21-49. 